\title{
Principles of practice parameters for the treatment of sleep disordered breathing in the elderly and frail elderly: the consensus of the International Geriatric Sleep Medicine Task Force
}

Nikolaus C. Netzer (Chair) ${ }^{1,2}$, Sonia Ancoli-Israel (Co-chair) ${ }^{3}$, Donald L. Bliwise ${ }^{4}$, Stephany Fulda ${ }^{5}$, Christine Roffe ${ }^{6}$, Fernanda Almeida ${ }^{7}$, Hakki Onen ${ }^{8}$, Fannie Onen ${ }^{9}$, Friedhart Raschke ${ }^{10}$, Miguel Angel Martinez Garcia ${ }^{11}$ and Helmut Frohnhofen ${ }^{12,13}$

\begin{abstract}
Affiliations: ${ }^{1}$ Hermann Buhl Institute for Hypoxia and Sleep Medicine Research, Dept of Sports Science, Faculty of Psychology and Sports Science, University Innsbruck, Austria. ${ }^{2}$ Division of Sports Medicine and Rehabilitation, Dept of Medicine, University Hospitals Ulm, Ulm, Germany. ${ }^{3}$ Depts of Psychiatry and Medicine, University of California, San Diego, CA, USA. "Sleep Program, Dept of Neurology, Emory University, Atlanta, GA, USA. ${ }^{5}$ Sleep and Epilepsy Center, Neurocenter of Southern Switzerland, Lugano, Switzerland. ${ }^{6}$ Institute for Science and Technology in Medicine, Keele University, Keele, UK. ${ }^{7}$ Dental Medical School, University of British Colombia, Vancouver, BC, Canada. ${ }^{8}$ Geriatric Sleep Center, Edouard Herriot University Hospital, HCL, Lyon, France. ${ }^{9}$ Dept of Geriatrics, Bichat University Hospital, APHP and INSERM U669, Paris, France. ${ }^{10}$ Institute for Rehabiltation Research, Hospital Norderney, Norderney, Germany. ${ }^{11}$ Respiratory Dept, La Fe University and Polytechnic Hospital, Valencia, Spain. ${ }^{12}$ Faculty of Health, Dept Medicine, University Witten-Herdecke, Witten, Germany. ${ }^{13}$ Dept of Geriatrics, Kliniken Essen Mitte, Essen, Germany.
\end{abstract}

Correspondence: Nikolaus C Netzer, Hermann Buhl Institute for Hypoxia and Sleep Medicine Research, Ghersburg Clinic for Geriatric Rehabilitation, Ghersburgstr. 9, 83043 Bad Aibling, Germany.

Email: nikolaus.netzer@uibk.ac.at

ABSTRACT Sleep disordered breathing (SDB) is a leading cause of morbidity worldwide. Its prevalence increases with age. Due to the demographic changes in industrial societies, pulmonologists and sleep physicians are confronted with a rapidly growing number of elderly SDB patients. For many physicians, it remains unclear how current guidelines for SDB management apply to elderly and frail elderly patients. The goal of this consensus statement is to provide guidance based on published evidence for SDB treatment in this specific patient group.

Clinicians and researchers with expertise in geriatric sleep medicine representing several countries were invited to participate in a task force. A literature search of PubMed from the past 12 years and a systematic review of evidence of studies deemed relevant was performed.

Recommendations for treatment management of elderly and frail elderly SDB patients based on published evidence were formulated via discussion and consensus.

In the last 12 years, there have been surprisingly few studies examining treatment of SDB in older adults and even fewer in frail older adults. Studies that have been conducted on the management of SDB in the older patient population were rarely stratified for age. Studies in SDB treatment that did include age stratification mainly focused on middle-aged and younger patient groups. Based on the evidence that is available, this consensus statement highlights the treatment forms that can be recommended for elderly SDB patients and encourages treatment of SDB in this large patient group.

@ERSpublications

An overview of the research in the field of and clinical guidelines for the treatment of SDB in elderly patients http://ow.ly/pfjr301FQur

Received: Nov 252015 | Accepted after revision: May 032016 | First published online: July 282016

Support statement: The authors thank the German Sleep Society for a partial sponsorship of the first initiating meeting of the Task Force in Berlin. Funding information for this article has been deposited with the Open Funder Registry.

Conflict of interest: Disclosures can be found alongside this article at erj.ersjournals.com

Copyright OERS 2016 


\section{Introduction}

The world today is facing an unprecedented ageing of the population. According to the World Health Organization, the number of people aged 65 years or older is projected to grow from an estimated 524 million in 2010 to nearly 1.5 billion in 2050, with most of the increase in developing countries [1].

The prevalence of sleep disordered breathing (SDB) in this age group, based on a definition of an apnoeahypopnoea index (AHI) (the number of apnoeas and hypopnoeas per hour of sleep) of at least 10, is over $20 \%$ in various epidemiological studies [2-4]. In frail elderly patients, prevalence rates reach as high as $60 \%$ [5]. These data suggest that in the future, sleep medicine health professionals will be increasingly asked to evaluate the need to treat SDB in elderly patients over 65 years of age.

This aged patient group can differ from younger or middle-aged patients with SDB in many ways. In fact, this large and growing population is a highly diverse group, as the ageing process varies from one individual to another. Some individuals age very well without serious disease and function perfectly in daily life, i.e. they experience "successful ageing" [6]. Other older adults have many comorbidities, several handicaps and several serious diseases, and consequently are frail. This phenomenon is named "pathological ageing". Yet other individuals are between the two categories, representing the "usual ageing" that may be associated with chronic but stable comorbidities, without significant dysfunction in daily life.

$\mathrm{SDB}$, in older populations as in younger ones, is associated with serious outcomes including stroke [7-9], occult nocturnal hypertension [10], open angle glaucoma [11], falls with fractures [12], impaired quality of life [13], decreased pain tolerance [14], frailty [15] and mortality [8, 9, 16, 17]. These potentially serious outcomes of SDB in elderly patients imply that treatment for SDB may be at least as necessary as in younger and middle-aged SDB patients. Effective treatment of the disorder has been associated with major improvements in pain tolerance [14], and in risk of falls [12] and stroke [9], as well as diminished risk of cardiovascular morbidity and mortality [17]. In view of these considerations, it should not be surprising that untreated SDB in older adults is associated with significant medical costs [18]. The potentially serious outcomes of SDB in elderly patients imply that treatment for SDB may be at least as necessary as in younger and middle-aged SDB patients.

Despite the high prevalence of SDB in the older populations, the condition is frequently unrecognised and undiagnosed even in geriatric settings $[18,19]$. Unfortunately, many older patients who do seek medical attention for SDB are dismissed as having no significant illness without formal assessment. At least three factors underlie the lack of recognition of SDB in older adults. 1) Clinical presentation of the disorder may often be atypical $[5,20,21]$, and history taking and the interpretation of signs and symptoms related to SDB are extremely difficult [22]. 2) Health professionals are not well prepared to screen and manage sleep problems, especially in older adults. The disparity between a high prevalence of undiagnosed obstructive sleep apnoea (OSA) in the population and the low level of clinical recognition has been recognised in different patient groups $[5,20,21]$. 3) Sleep laboratories are not easily accessible to many frail older adults living in nursing homes and long-term care units. 4) We have difficulties knowing at which degree of severity and AHI SDB in the elderly is pathological or just a part of physiological ageing.

Regarding the latter issue, the low diagnostic rate of SDB in elderly might change with the changing diagnostic policies for SDB by healthcare insurers and providers. For example, in lieu of sleep laboratory-based polysomnography (PSG), home sleep testing may now be covered in many countries. Regardless of which test is performed, older patients should be evaluated with a comprehensive geriatric assessment $[23,24]$. Nevertheless, treatment outcomes regarding clinical symptoms, for example, excessive daytime sleepiness, might be different in the different age groups, as shown in the Stuart/Florida cohort of the Sleep in Primary Care Study [20].

Although in past decades and more recently, there have been several reviews and meta-analyses that have helped define therapeutic management for OSA [25-29], the majority of these have focused on middle-aged populations. Given the uncertainty regarding effects of OSA treatment in elderly populations, we undertook a consensus process to analyse all treatment studies in older populations with SDB performed in the last 12 years. Our goal was to develop evidence-based practice recommendations. This article is an outcome of that process.

\section{Methods}

On invitation by the Geriatric Assembly of the German Sleep Society (DGSM) and individual members (N.C. Netzer and F. Almeida) of the Sleep and Respiratory Neurology Assembly of the American Thoracic Society (ATS), 11 experts in geriatric sleep medicine formed a panel representative of the diversity of opinions from the Americas and Europe, and who were members of the several societies involved in guidelines for SDB therapy, namely ATS, the European Respiratory Society, the American Academy of Sleep Medicine (AASM), the Sleep Research Society and the European Sleep Research Society. In addition, 
the group aimed to cover different fields involved in the treatment of SDB, namely psychiatry, pulmonary medicine, geriatric medicine, dentistry, neurology, behavioural science and airway physiology.

The panel met for the first time in Berlin, Germany, in December 2012 and thereafter on several other occasions at various sites in 2013-2015, and decided on the structure of a systematic review of publications covering therapy of SDB in older patients. After much discussion, there was consensus to define "older" as aged 65 years and over as this age is the most frequently used cut-off for elderly in the scientific literature. Papers were only included in this review if the population studied included patients with a mean age of 65 or older, a majority of patients 65 years of age or older, or included older adults of 65 years and older in their sample and gave the results stratified by age (i.e. were results in the older adults the same or different than in the younger adults?).

PubMed/Medline publications from the 12 years until May 31, 2015, were searched with keywords "sleep disordered breathing", "sleep apnea", "OSA", "OSAS”, "OSAHS”, “central sleep apnea”, "therapy”, "aged” and "elderly". This resulted in a total of 1740 publications with abstracts in the English language. A team of two panel members reviewed the literature to examine how many studies were primarily on older adults and fulfilled the aforementioned inclusion criteria. In a second step, a team of two other panel members performed a second screening of the 1740 abstracts based on the sole criteria of whether the publication dealt with SDB therapy in the geriatric age group. This resulted in a total of 178 publications (all in the English language) meeting these criteria.

The 178 full papers were then distributed to five teams of two panel members each. The scoring teams were formed with the following subspecialties within the panel: noninvasive ventilation therapy, dental and oral appliance therapy, cardiological and surgical therapy, supplemental oxygen therapy, and alternative treatment options including drugs.

Each paper was evaluated for whether it met the inclusion criteria and each was scored for the evidence level based on the Grading of Recommendations Assessment, Development and Evaluation (GRADE) working group's four evidence levels: "high", "moderate", "low" and "very low" [30] and, in parallel, each paper was scored according to the Scottish Intercollegiate Guidelines Network (SIGN) grading (table 1) [31]. SIGN was chosen parallel to GRADE to determine evidence levels of studies because it ranks original randomised controlled studies highest, before meta-analyses, which seemed to be more appropriate for the development of principle of practice parameters than the usual evidence grading, which ranks meta-analyses in the highest position, and because it gives in addition to GRADE (four levels), a higher differentiation of evidence of papers into eight levels (1++-4). In addition, a Jadad score was assigned to each study to assess the level of possible bias of each study (table 2) [32]. For the clinical recommendations or guidelines, the GRADE ranking for "strong" or "weak" from the GRADE working group has been applied [30].

Each team created a table of publications that fulfilled the inclusion criteria and wrote the corresponding section of this article. When there were insufficient numbers of publications meeting the inclusion criteria, results from publications in younger adults were summarised with the understanding that those results may or may not apply to the elderly and the frail elderly. Each team also provided recommendations for the principle of practice parameters within their subspecialty. The final recommendations of the expert consensus for each treatment are presented at the end of each section.

\section{TABLE 1 Grading of papers with the Scottish Intercollegiate Grading Network for evidence level}

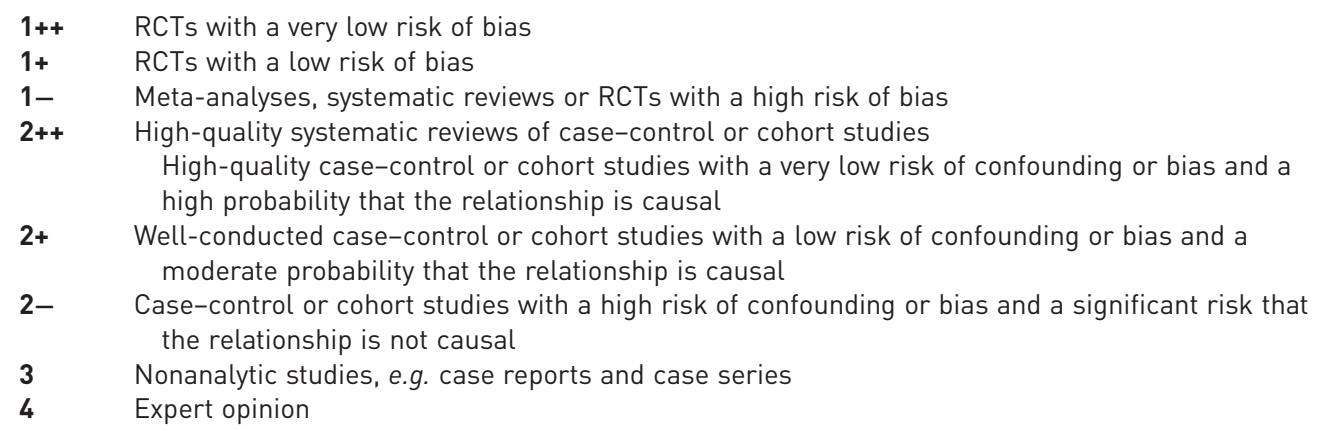

RCT: randomised controlled trial. Reproduced and modified from [31] with permission from the publisher. 
TABLE 2 Jadad score for blinding and randomisation (0-5 points)

\begin{tabular}{lccc} 
Question & 2 points & 1 point & points \\
\hline $\begin{array}{l}\text { 1) Was the study described } \\
\text { as randomised? }\end{array}$ & $\begin{array}{c}\text { The method of randomisation was } \\
\text { described and that method was } \\
\text { appropriate }\end{array}$ & $\begin{array}{c}\text { The method of } \\
\text { randomisation was } \\
\text { described }\end{array}$ & $\begin{array}{c}\text { The method of randomisation was not } \\
\text { described or was described but } \\
\text { inappropriate }\end{array}$ \\
$\begin{array}{l}\text { 2) Was the study described } \\
\text { as double blind? }\end{array}$ & $\begin{array}{c}\text { The method of blinding was described } \\
\text { and that method was appropriate }\end{array}$ & $\begin{array}{c}\text { The method of blinding } \\
\text { was described }\end{array}$ & $\begin{array}{c}\text { The method of blinding was not } \\
\text { described or was described but } \\
\text { inappropriate }\end{array}$ \\
$\begin{array}{l}\text { 3) Was there a description of } \\
\text { withdrawals and } \\
\text { dropouts? }\end{array}$ & Yes & No or do not know
\end{tabular}

\#: to receive the point, an article should describe the number of withdrawals and dropouts in each of the study groups, and the underlying reasons.

\section{Evaluation and clinical recommendations \\ Positive airway pressure and servoventilation treatment}

It is well documented that OSA is well treated with positive airway pressure (PAP). There have been many studies on the effect of treating OSA on outcomes other than apnoea-related symptoms, such as heart failure, hypertension and diabetes; however, few of these studies have been conducted on older adults or in the frail elderly. Only 29 papers met the inclusion criteria; these 29 were reviewed and evaluated, and are presented in table 3. Two of the studies reviewed stratified the results by age and five article represented different components of a single clinical trial.

The majority of the studies $(\mathrm{n}=21)$ evaluated populations with medical comorbidities more prevalent in older adults (e.g. dementia, Parkinson's disease, stroke, heart failure and chronic obstructive pulmonary disease (COPD)) and the main outcomes were the effect of PAP treatment on either apnoea or some aspect of that comorbidity. As can be seen in table 3, the evidence levels of these studies ranged from high of $1++$ (one study) [49] to low of 2-. Only 13 were randomised controlled trials (RCTs), the rest being observational in nature. The Jadad scores for 20 publications were in the $0-3$ range suggesting a higher risk of bias; eight were scored in the 4-5 range suggesting a lower risk and a higher quality study. Sample sizes ranged from a handful to $>4000$.

\section{Heart failure or cardiovascular disease}

Nine of the studies had a primary outcome of some form of heart disease, hypertension or renal disease measures [34, 35, 37, 42, 44, 47, 50, 57,60]. Results of these studies suggested that continuous positive airway pressure (CPAP) or adaptive servoventilation (ASV) treatment of the OSA and/or central sleep apnoes (CSA) resulted in overall improvement in the primary outcome measures. These results were often compared to either no-treatment groups or groups of noncompliant PAP patients. Most of these studies, however, were observational cohort studies; only three were RCTs [34, 49, 60]. Preliminary results from a major RCT, the Adaptive Servo-Ventilation for Central Sleep Apnea in Systolic Heart Failure (SERVE-HF) study, have been reported recently [45], and suggest that ASV specifically may have detrimental effects in chronic heart failure $(\mathrm{CHF})$ patients with an ejection fraction of $\geqslant 45 \%$ across a broad age range who have predominantly central sleep apnoea, so the value of this particular type of PAP delivery in some elderly patients with heart failure remains uncertain.

\section{Overlap syndrome}

Although one might suspect that the overlap of OSA and COPD should be very common in the elderly OSA patient group, because COPD is very common in elderly patients, only one study was found that fulfilled the inclusion criteria. This high-quality cohort study not only had a large elderly cohort in an overlap patient group, it was also stratified for age [45]. The retrospective analysis of almost 800 sleep laboratory patients revealed that the prevalence of the overlap syndrome is significantly higher in elderly OSA patients compared to younger and middle-aged patients, and that auto-CPAP and bilevel CPAP lead to a significant improvement of blood gases over a longer period of time in comparison to patients who were noncompliant to CPAP or patients who had COPD alone.

\section{Stroke}

Three studies either included stroke patients as the full sample or had stroke as the primary outcome [38, $43,46]$, and one study had mortality due to stroke as a secondary outcome [46]. Two of the four studies 
TABLE 3 Studies evaluating positive airway pressure (PAP) use in older adults

\begin{tabular}{|c|c|c|c|c|c|c|c|c|c|c|c|}
\hline First author [ref.] & Participants & Age years & $\begin{array}{c}\text { Participant } \\
\text { characteristics }\end{array}$ & Main outcomes & Type of study & $\begin{array}{l}\text { Treatment } \\
\text { duration }\end{array}$ & Compliance & $\begin{array}{l}\text { Jadad } \\
\text { score }\end{array}$ & $\begin{array}{c}\text { Evidence } \\
\text { level }^{\#}\end{array}$ & $\begin{array}{c}\text { GRADE } \\
\text { level }\end{array}$ & Study conclusions \\
\hline Ancoli-Israel [33] & $\begin{array}{l}\text { CPAP, } n=19 ; \\
\text { placebo CPAP, } \\
\quad n=20\end{array}$ & $\begin{array}{l}\text { Range 55-91; } \\
\text { CPAP mean 79; } \\
\text { placebo CPAP } \\
\text { mean } 78\end{array}$ & $\begin{array}{c}\text { OSA (AHI } \\
>10 \text { events per } h \text { ) } \\
+ \text { AD }\end{array}$ & Cognition & $\mathrm{RCT}$ & $\begin{array}{l}\text { CPAP, } 6 \text { weeks; } \\
\text { placebo CPAP, } \\
3 \text { weeks } \\
\text { followed by } \\
3 \text { weeks of } \\
\text { therapeutic } \\
\text { CPAP }\end{array}$ & $5.8 \mathrm{~h}$ & 4 & $1+$ & High & $\begin{array}{c}\text { Comparison of CPAP } \\
\text { versus placebo CPAP at } \\
3 \text { weeks suggested no } \\
\text { significant improvements in } \\
\text { cognition but was } \\
\text { underpowered; comparison } \\
\text { pre- and post-treatment } \\
\text { after } 3 \text { weeks of } \\
\text { therapeutic CPAP showed } \\
\text { significant improvement in } \\
\text { cognition }\end{array}$ \\
\hline ARZt [34] & $\begin{array}{c}\text { CPAP, } \mathrm{n}=128 ; \\
\text { control, } \mathrm{n}=110 \\
\text { CPAP patients } \\
\text { divided post } \\
\text { hoc into } \\
\text { AHI<15 events } \\
\text { per } \mathrm{h} \text { with } \\
\text { treatment } \\
\text { ICPAP CSA } \\
\text { suppressed, } \\
\mathrm{n}=57 ; \text { CPAP } \\
\text { CSA } \\
\text { unsuppressed, } \\
\mathrm{n}=43\end{array}$ & $\begin{array}{c}\text { Range NR; } \\
\text { control, mean 64; } \\
\text { CPAP CSA } \\
\text { suppressed, } \\
\text { mean 60; } \\
\text { CPAP CSA } \\
\text { unsuppressed, } \\
\text { mean } 65\end{array}$ & $\begin{array}{l}\text { CSA }(\text { AHI }>15 \\
\text { events per } h \text { ) } \\
\text { theart failure }\end{array}$ & $\begin{array}{l}\text { LVEF, heart } \\
\text { transplant-free } \\
\text { survival }\end{array}$ & RCT & 24 months & $\begin{array}{l}3 \text { months, } 4.4 \mathrm{~h} ; \\
12 \text { months, } \\
3.6 \mathrm{~h}\end{array}$ & 3 & $1-$ & Moderate & $\begin{array}{l}\text { CPAP CSA suppressed } \\
\text { subjects had greater } \\
\text { increase in LVEF at } \\
3 \text { months and significantly } \\
\text { better transplant-free } \\
\text { survival than controls; } \\
\text { CPAP CSA unsuppressed } \\
\text { group did not differ } \\
\text { from controls }\end{array}$ \\
\hline ARZT [35] & $\begin{array}{l}\text { CPAP, } n=10 \\
\text { BiPAP, } n=4\end{array}$ & $\begin{array}{l}\text { Range } 18-80 ; \\
\text { mean } 65\end{array}$ & $\begin{array}{l}\text { CHF+CSR-CSA } \\
\text { (AHI >15 events } \\
\text { per h) land } \\
\text { residual } \\
\text { CSA on PAP) }\end{array}$ & $\mathrm{AHI}$ & $\cos$ & 3 nights & NR & 0 & $2-$ & Low & $\begin{array}{l}\text { Flow-targeted dynamic } \\
\text { BiPAP support effectively } \\
\text { suppresses CSR-CSA in } \\
\text { patients with CHF and is } \\
\text { well tolerated }\end{array}$ \\
\hline AyALon [36] & $\begin{array}{c}\text { CPAP, } n=14 ; \\
\text { placebo CPAP, } \\
n=16\end{array}$ & $\begin{array}{l}\text { Range } 53-91 ; \\
\text { mean } 78\end{array}$ & $\begin{array}{c}\text { OSA (AHI } \\
>10 \text { events per } h \text { ) } \\
+ \text { AD }\end{array}$ & $\begin{array}{l}\text { Adherence, } \\
\text { depression }\end{array}$ & RCT & 3 weeks & $4.8 \mathrm{~h}$ & 4 & $1+$ & Moderate & $\begin{array}{l}\text { Patients wore CPAP for } \\
4.8 \mathrm{~h} \text { per night; more } \\
\text { depressive symptoms were } \\
\text { associated with worse } \\
\text { adherence, OSA+AD } \\
\text { patients tolerate CPAP; } \\
\text { adherence and long-term } \\
\text { use may be more difficult } \\
\text { mong those patients with } \\
\text { more depressive symptoms }\end{array}$ \\
\hline Bravata [37] & $\begin{array}{c}\text { AutoPAP, } \\
n=45 ; \\
\text { untreated } \\
\text { control, } n=25\end{array}$ & $\begin{array}{l}\text { AutoPAP, mean } \\
66 \text { (range 47-88); } \\
\text { control, mean 67 } \\
\text { (range 45-88) }\end{array}$ & $\begin{array}{l}\text { OSA (AHI } \\
>5 \text { events per h) } \\
+ \text { TIA }\end{array}$ & $\begin{array}{l}\text { Effect of autoPAP } \\
\text { on OSA, autoPAP } \\
\text { adherence, } \\
\text { recurrence of } \\
\text { TIAs }\end{array}$ & $\mathrm{RCT}$ & $\begin{array}{l}\text { Observation } \\
\text { period for } \\
90 \text { days }\end{array}$ & $5.6 \mathrm{~h}$ & 3 & $2-$ & Moderate & $\begin{array}{l}\text { AutoPAP tolerated; trend } \\
\text { for recurrent events to be } \\
\text { more frequent in controls }\end{array}$ \\
\hline
\end{tabular}




\begin{tabular}{|c|c|c|c|c|c|c|c|c|c|c|c|}
\hline First author [ref.] & Participants & Age years & $\begin{array}{c}\text { Participant } \\
\text { characteristics }\end{array}$ & Main outcomes & Type of study & $\begin{array}{l}\text { Treatment } \\
\text { duration }\end{array}$ & Compliance & $\begin{array}{l}\text { Jadad } \\
\text { score }\end{array}$ & $\begin{array}{l}\text { Evidence } \\
\text { level }^{\#}\end{array}$ & $\begin{array}{l}\text { GRADE } \\
\text { level }\end{array}$ & Study conclusions \\
\hline Bravata [38] & $\begin{array}{c}\text { AutoPAP, } \\
n=31 ; \\
\text { untreated } \\
\text { control, } n=24\end{array}$ & $\begin{array}{l}\text { Range 50-94; } \\
\text { autoPAP, } \\
\text { mean } 71 ; \text { control, } \\
\text { mean } 72\end{array}$ & $\begin{array}{c}\text { OSA }(\mathrm{AHI}>10 \\
\text { events per } \mathrm{h}) \\
\text { +acute ischaemic } \\
\text { stroke }\end{array}$ & $\begin{array}{l}\text { Effect on OSA, } \\
\text { adherence, NIH } \\
\text { Stroke Scale }\end{array}$ & $\mathrm{RCT}$ & 30 days & $5.1 \mathrm{~h}$ & 3 & $1-$ & High & $\begin{array}{c}\text { OSA reduced, compliance } \\
\text { and greater improvement } \\
\text { in NIH Stroke Scale in } \\
\text { autoPAP users }\end{array}$ \\
\hline Сhong [39] & $\begin{array}{c}\text { CPAP, } n=19 ; \\
\text { placebo CPAP, } \\
n=20\end{array}$ & $\begin{array}{l}\text { Range } 55-91 ; \\
\text { CPAP mean } 79 ; \\
\text { placebo CPAP, } \\
\text { mean } 78\end{array}$ & $\begin{array}{l}\text { OSA (AHI } \\
>10 \text { events per } h) \\
\quad+A D\end{array}$ & $\begin{array}{c}\text { Daytime } \\
\text { sleepiness (ESS) }\end{array}$ & $\mathrm{RCT}$ & $\begin{array}{l}\text { CPAP, } 6 \text { weeks; } \\
\text { placebo CPAP, } \\
3 \text { weeks } \\
\text { followed by } \\
3 \text { weeks of } \\
\text { therapeutic } \\
\text { CPAP }\end{array}$ & NR & 4 & $1+$ & High & $\begin{array}{c}\text { CPAP, compared to } \\
\text { placebo, improved daytime } \\
\text { sleepiness }\end{array}$ \\
\hline COOKE [40] & $\begin{array}{c}\text { CPAP, } n=27 ; \\
\text { placebo CPAP, } \\
n=25\end{array}$ & $\begin{array}{c}\text { Range, NR; } \\
\text { CPAP, mean 79; } \\
\text { placebo CPAP, } \\
\text { mean } 78\end{array}$ & $\begin{array}{l}\text { OSA (AHI>10 } \\
\text { events per } h) \\
\quad+A D\end{array}$ & $\begin{array}{l}\text { Sleep macro- and } \\
\text { microarchitecture }\end{array}$ & RCT & $\begin{array}{l}\text { CPAP, } 6 \text { weeks; } \\
\text { placebo CPAP, } \\
3 \text { weeks } \\
\text { followed by } \\
3 \text { weeks of } \\
\text { therapeutic } \\
\text { CPAP }\end{array}$ & $5.5 \mathrm{~h}$ & 4 & $1+$ & High & $\begin{array}{l}\text { CPAP improves both } \\
\text { macro- and } \\
\text { microarchitecture }\end{array}$ \\
\hline COOKE [41] & $\begin{array}{c}\text { CPAP, } n=5 \\
\text { placebo CPAP, } \\
n=5\end{array}$ & $\begin{array}{l}\text { Range } 64-84 ; \\
\text { mean } 76\end{array}$ & $\begin{array}{c}\text { OSA (AHI } \\
>10 \text { events per h) } \\
\quad+A D\end{array}$ & Cognition, mood & $\cos$ & $\begin{array}{l}\text { CPAP users for } \\
13 \text { months } \\
\text { versus CPAP } \\
\text { nonusers }\end{array}$ & $\begin{array}{l}\text { Monitored but } \\
\text { NR }\end{array}$ & 1 & $2-$ & Low & $\begin{array}{l}\text { Long-term use of CPAP } \\
\text { associated with improved } \\
\text { or stable cognition and } \\
\text { mood }\end{array}$ \\
\hline DонІ [42] & $\begin{array}{l}\text { CPAP, } n=11 ; \\
\text { BiPAP } \\
\text { lunresponsive } \\
\text { to CPAP), } n=9\end{array}$ & $\begin{array}{l}\text { Range, NR; } \\
\text { CPAP, mean } 65 ; \\
\text { BiPAP, mean } 68\end{array}$ & $\begin{array}{l}\text { CSA (AHI } \\
>15 \text { events per } h \text { ) } \\
+ \text { LVHF }\end{array}$ & $\begin{array}{c}\text { LVEF; plasma } \\
\text { BNP }\end{array}$ & OS & 6 months & NR & 0 & $2-$ & Low & $\begin{array}{l}\text { BNP levels significantly } \\
\text { decreased and LVEF } \\
\text { significantly increased in } \\
\text { both groups; BiPAP is an } \\
\text { effective alternative for } \\
\text { patients with LVHF and } \\
\text { pure CSR-CSA who are } \\
\text { unresponsive to CPAP }\end{array}$ \\
\hline Hsu [43] & $\begin{array}{c}\text { CPAP, } n=15 ; \\
\text { control } \\
\text { (conventional } \\
\text { treatment), } \\
n=15\end{array}$ & $\begin{array}{l}\text { Range, NR; } \\
\text { CPAP, mean 73; } \\
\text { control, mean } 74\end{array}$ & $\begin{array}{l}\text { OSA }(\mathrm{AHI}>30 \\
\text { events per h) } \\
+ \text { stroke }\end{array}$ & $\begin{array}{c}\text { Primary: } \\
\text { activities of daily } \\
\text { living; secondary: } \\
\text { hypertension, } \\
\text { daytime } \\
\text { sleepiness, } \\
\text { cognitive } \\
\text { function, anxiety, } \\
\text { depression, QOL }\end{array}$ & RCT & 80 days & $1.4 \mathrm{~h}$ & 5 & $1-$ & High & $\begin{array}{l}\text { CPAP use averaged } 1.4 \mathrm{~h} \text { a } \\
\text { night; CPAP treatment } \\
\text { resulted in no significant } \\
\text { improvements in any } \\
\text { outcome measures }\end{array}$ \\
\hline KoYama [44] & $\begin{array}{c}\text { ASV, } n=27 \\
\text { untreated } \\
\text { control, } n=16\end{array}$ & Mean 74 & $\begin{array}{l}\text { OSA }(\mathrm{AHI}>15 \\
\text { events per h) } \\
\quad+\mathrm{CHF}\end{array}$ & $\begin{array}{l}\text { LVEF; BNP; } \\
\text { C-reactive } \\
\text { protein; eGFR }\end{array}$ & $\cos$ & 12 months & $\begin{array}{c}\text { Recorded but } \\
\text { NR }\end{array}$ & 1 & $2-$ & Low & $\begin{array}{l}\text { ASV associated with } \\
\text { improved eGFR and LVEF; } \\
\text { ASV therapy could improve } \\
\text { renal dysfunction in CHF } \\
\text { patients through } \\
\text { haemodynamic support }\end{array}$ \\
\hline
\end{tabular}




\begin{tabular}{|c|c|c|c|c|c|c|c|c|c|c|c|}
\hline First author [ref.] & Participants & Age years & $\begin{array}{c}\text { Participant } \\
\text { characteristics }\end{array}$ & Main outcomes & Type of study & $\begin{array}{l}\text { Treatment } \\
\text { duration }\end{array}$ & Compliance & $\begin{array}{l}\text { Jadad } \\
\text { score }\end{array}$ & $\begin{array}{l}\text { Evidence } \\
\text { level }^{\#}\end{array}$ & $\begin{array}{l}\text { GRADE } \\
\text { level }\end{array}$ & Study conclusions \\
\hline LACEDONIA [45] & $\begin{array}{l}\text { CPAP plus } \mathrm{O}_{2} \\
\text { if positive for } \\
\text { T30, } n=168\end{array}$ & $\begin{array}{l}\text { Mean } 68, \text { age } \\
\text { stratified }\end{array}$ & $\begin{array}{c}\text { Overlap OSA } \\
+ \text { COPD, mean AHI } \\
42 \text { events per } \mathrm{h}\end{array}$ & $P_{\mathrm{aO}_{2}}$ and $\mathrm{PaCO}_{2}$ & $\cos$ & 12 months & $\begin{array}{c}\text { Recorded but } \\
\text { NR }\end{array}$ & 1 & $2++$ & Moderate & $\begin{array}{l}\text { Overlap syndrome was } \\
\text { more common in the } \\
\text { elderly; } \mathrm{PaO}_{2} \text { in compliant } \\
\text { elderly patients with } \\
\text { overlap syndrome improved } \\
\text { significantly with CPAP but } \\
\text { not in patients with COPD } \\
\text { only }\end{array}$ \\
\hline Martínez-García [46] & $\begin{array}{c}\text { CPAP } \\
\text { compliers, } \\
n=15 ; \text { CPAP } \\
\text { noncompliers, } \\
n=36\end{array}$ & $\begin{array}{l}\text { Range } 57-82 ; \\
\text { CPAP, mean } 73 ; \\
\text { CPAP } \\
\text { noncompliers, } \\
\text { mean } 72\end{array}$ & $\begin{array}{l}\text { Ischaemic stroke } \\
\text { or TIA, OSA (AHI } \\
\text { >20 events per h) }\end{array}$ & Vascular events & $\cos$ & 18 months & $5.7 \mathrm{~h}$ & 0 & $2-$ & Low & $\begin{array}{l}\text { Compared to CPAP } \\
\text { compliers, the incidence of } \\
\text { new vascular events was } \\
\text { greater in CPAP } \\
\text { noncompliers; risk of new } \\
\text { vascular event was } 5 \text {-fold } \\
\text { greater in noncompliers }\end{array}$ \\
\hline MaRtínez-García [47] & $\begin{array}{c}n=939 ; \\
\text { control lAHI } \\
<15 \text { events per } \\
\text { h], } n=155 ; \text { AHI } \\
15-29 \text { events } \\
\text { per } h \text { without } \\
\text { CPAP, } n=108 ; \\
\text { AHI > } 30 \text { events } \\
\text { per h without } \\
\text { CPAP, } n=173 ; \\
\text { OSA }+ \text { CPAP, } \\
n=503\end{array}$ & $\begin{array}{c}\text { Control, mean } 71 \text {; } \\
\text { AHI } 15-29 \text { events } \\
\text { per } h \text { without } \\
\text { CPAP, mean } 72 ; \\
\text { AHI >30 events } \\
\text { per h without } \\
\text { CPAP, mean } 72 ; \\
\text { OSA+CPAP, mean } \\
70\end{array}$ & 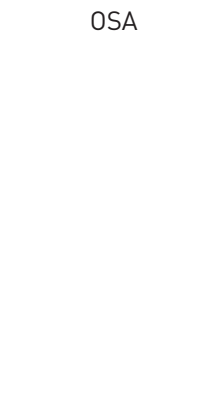 & $\begin{array}{c}\text { Primary: } \\
\text { cardiovascular } \\
\text { death; secondary: } \\
\text { all-cause } \\
\text { mortality and } \\
\text { mortality from } \\
\text { stroke, heart } \\
\text { failure and } \\
\text { myocardial } \\
\text { infarction }\end{array}$ & $\cos$ & 69 months & $\begin{array}{l}\text { Measured as } \\
>4 \mathrm{~h}^{- \text {day }^{-1}}\end{array}$ & 1 & $2-$ & Moderate & $\begin{array}{l}\text { Severe OSA not treated } \\
\text { with CPAP is associated } \\
\text { with cardiovascular death } \\
\text { in the elderly and adequate } \\
\text { CPAP treatment may } \\
\text { reduce this risk }\end{array}$ \\
\hline Neikrug [48] & $\begin{array}{c}\text { CPAP, } n=19 ; \\
\text { placebo CPAP, } \\
n=19\end{array}$ & $\begin{array}{l}\text { Range, NR; } \\
\text { CPAP, mean 68; } \\
\text { placebo CPAP, } \\
\text { mean } 67\end{array}$ & $\begin{array}{c}\text { OSA (AHI } \\
>10 \text { events per h) } \\
\text { and OSA (AHI } \\
>10 \text { events per } \mathrm{h}) \\
+\mathrm{PD}\end{array}$ & $\begin{array}{c}\text { PSG: sleep } \\
\text { efficiency, \% } \\
\text { sleep stages (N1, } \\
\text { N2, N3, R), } \\
\text { arousal index, } \\
\text { AHI, and \% time } \\
\mathrm{O}_{2} \text { saturation } \\
<90 \% \text {; MSLT: } \\
\text { mean } \\
\text { sleep-onset } \\
\text { latency }\end{array}$ & $\mathrm{RCT}$ & $\begin{array}{l}\text { CPAP, } 6 \text { weeks; } \\
\text { placebo CPAP, } \\
3 \text { weeks } \\
\text { followed by } \\
3 \text { weeks of } \\
\text { therapeutic } \\
\text { CPAP }\end{array}$ & $5.2 \mathrm{~h}$ & 5 & $1+$ & High & $\begin{array}{l}\text { CPAP versus placebo was } \\
\text { effective in reducing } \\
\text { apnoea events, improving } \\
\mathrm{O}_{2} \text { saturation and } \\
\text { deepening sleep in patients } \\
\text { with PD and OSA; arousal } \\
\text { index and daytime } \\
\text { sleepiness were reduced }\end{array}$ \\
\hline RANDERATH [49] & $\begin{array}{l}\text { ASV, } n=31 ; \\
\text { CPAP, } n=32\end{array}$ & $\begin{array}{l}\text { CPAP, mean 67.4; } \\
\text { ASV, mean } 65.3\end{array}$ & $\begin{array}{c}\text { OSA+CSA (AHI } \\
>15 \text { events per h) } \\
+ \text { CHF }\end{array}$ & LVEF, BNP & $\mathrm{RCT}$ & 12 months & $\begin{array}{l}\text { CPAP, } 4.3 \mathrm{~h} \text {; } \\
\text { ASV, } 5.2 \mathrm{~h}\end{array}$ & 5 & $1++$ & High & $\begin{array}{l}\text { BNP improved with ASV } \\
\text { relative to CPAP }\end{array}$ \\
\hline TAKAMA [50] & ASV, $n=61$ & Mean 70 & $\mathrm{CHF}$ & LVEF; BNP & $\cos$ & 6 months & NR & 1 & $2-$ & Moderate & $\begin{array}{l}\text { Both LVEF and BNP } \\
\text { improved }\end{array}$ \\
\hline
\end{tabular}




\begin{tabular}{|c|c|c|c|c|c|c|c|c|c|c|c|}
\hline First author [ref.] & Participants & Age years & $\begin{array}{c}\text { Participant } \\
\text { characteristics }\end{array}$ & Main outcomes & Type of study & $\begin{array}{l}\text { Treatment } \\
\text { duration }\end{array}$ & Compliance & $\begin{array}{l}\text { Jadad } \\
\text { score }\end{array}$ & $\begin{array}{c}\text { Evidence } \\
\text { level }^{\#}\end{array}$ & $\begin{array}{l}\text { GRADE } \\
\text { level }\end{array}$ & Study conclusions \\
\hline YANG $[51]$ & 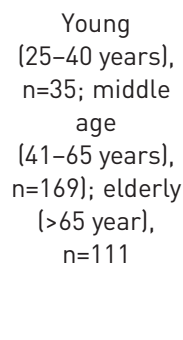 & NR & $\begin{array}{l}\text { OSA (AHI >5 } \\
\text { events per } h \text { ) }\end{array}$ & CPAP adherence & $\cos$ & 2 weeks & See comments & 1 & $2-$ & Moderate & $\begin{array}{l}\text { Lower acceptance in } \\
\text { elderly than younger but no } \\
\text { difference in hours used } \\
\text { for compliers; CPAP } \\
\text { acceptance is low in elderly } \\
\text { patients in Taiwan; CPAP } \\
\text { acceptance, instead of } \\
\text { CPAP adherence, is the } \\
\text { critical issue with elderly } \\
\text { patients with OSA }\end{array}$ \\
\hline WoeHrLe [52] & $n=4281$ & $\begin{array}{c}\text { Range, }<40-\geqslant 70 \\
\text { mean } 58\end{array}$ & OSA (AHI NR) & CPAP adherence & OS & 3.5 years & $\begin{array}{l}<40 \text { years: } \\
368 \pm 89 \text { min; } \\
>40-50 \text { years: } \\
363 \pm 88 \text { min; } \\
>50-60 \text { years: } \\
368 \pm 91 \mathrm{~min} ; \\
>60-70 \text { years: } \\
385 \pm 97 \text { min; } \\
>70 \text { years: } \\
392 \pm 101 \text { min }\end{array}$ & 0 & $2-$ & Low & Adherence high \\
\hline YAGIHARA [53] & $\begin{array}{c}\text { OSA, } n=30 ; n o \\
\text { OSA, } n=27\end{array}$ & $\begin{array}{l}\text { Range, 60-75; } \\
\text { OSA, mean 66; no } \\
\text { OSA, mean } 66\end{array}$ & $\begin{array}{c}\text { OSA (AHI >20 } \\
\text { events per h); no } \\
\text { OSA (AHI <10 } \\
\text { events per h) }\end{array}$ & $\begin{array}{l}\text { Oxidative stress; } \\
\text { QOL }\end{array}$ & $\cos$ & 6 months & NR & 0 & $2-$ & Low & $\begin{array}{l}\text { CPAP in elderly patients } \\
\text { reduced oxidative stress } \\
\text { and improved QOL }\end{array}$ \\
\hline NG [54] & $\begin{array}{l}\text { Elderly Hong } \\
\text { Kong } \\
\text { population, } \\
n=819 ; \text { OSA, } \\
n=161\end{array}$ & Mean 73.9 & $\begin{array}{l}\text { Elderly average } \\
\text { population, } \\
\text { subgroup OSA }\end{array}$ & $\begin{array}{l}\text { CPAP acceptance } \\
\text { and adherence }\end{array}$ & $\cos$ & 12 months & $\begin{array}{c}\text { CPAP } \\
\text { acceptance, } \\
\text { hourly use NR }\end{array}$ & 0 & $2-$ & Low & $\begin{array}{l}\text { CPAP acceptance was } \\
21.3 \% \text {; those who used } \\
\text { CPAP had significant } \\
\text { improvement in SAQLI and } \\
\text { cognitive function; AHI of } \\
\text { CPAP accepters and } \\
\text { refusers did not differ } \\
\text { significantly }\end{array}$ \\
\hline McMILAN [55] & $\begin{array}{c}\mathrm{N}=278 ; \mathrm{CPAP}, \\
\mathrm{n}=140 ; \mathrm{BSC}, \\
\mathrm{n}=138\end{array}$ & Mean 71.1 & $\begin{array}{l}\text { OSA population } \\
>65 \text { years old }\end{array}$ & $\begin{array}{c}\text { Daytime } \\
\text { sleepiness (ESS), } \\
\text { lipids, mobility, } \\
\text { mood, cognitive } \\
\text { function, } \\
\text { cost-effectiveness }\end{array}$ & $\mathrm{RCT}$ & $\begin{array}{c}3 \text { and } \\
12 \text { months }\end{array}$ & $\begin{array}{c}\text { Median use } \\
\text { between } 1 \mathrm{~h} \text {, } \\
52 \mathrm{~min} \text { and } 2 \mathrm{~h} \\
22 \mathrm{~min} ; 35 \% \\
\text { used }>4 \mathrm{~h} \text { per } \\
\text { night }\end{array}$ & 4 & $1+$ & High & $\begin{array}{c}\text { ESS and lipids significantly } \\
\text { lower in CPAP versus BSC; } \\
\text { mobility improved } \\
\text { significantly in CPAP versus } \\
\text { BSC; no difference in mood } \\
\text { or cognitive function; CPAP } \\
\text { less expensive than or as } \\
\text { expensive as BSC }\end{array}$ \\
\hline
\end{tabular}




\begin{tabular}{|c|c|c|c|c|c|c|c|c|c|c|c|}
\hline First author [ref.] & Participants & Age years & $\begin{array}{c}\text { Participant } \\
\text { characteristics }\end{array}$ & Main outcomes & Type of study & $\begin{array}{l}\text { Treatment } \\
\text { duration }\end{array}$ & Compliance & $\begin{array}{l}\text { Jadad } \\
\text { score }\end{array}$ & $\begin{array}{l}\text { Evidence } \\
\text { level }^{\#}\end{array}$ & $\begin{array}{c}\text { GRADE } \\
\text { level }\end{array}$ & Study conclusions \\
\hline CRAWFORD-Achour [56] & $\begin{array}{c}\mathrm{N}=126 \\
\text { analysed as } \\
\text { part of proof } \\
\text { cohort study; } \\
\text { CPAP, } \mathrm{n}=33 ; \\
\text { no CPAP, } \mathrm{n}=93\end{array}$ & $\geqslant 65$ & OSA patients & $\begin{array}{l}\text { Cognitve function } \\
\text { tests }\end{array}$ & $\cos$ & 10 years & $\begin{array}{l}>6 \text { h CPAP use, } \\
\text { self reported }\end{array}$ & 1 & $2-$ & Moderate & $\begin{array}{l}\text { Cognitive function } \\
\text { improved significantly in } \\
\text { CPAP versus no CPAP }\end{array}$ \\
\hline GaLeTKe [57] & $\begin{array}{c}\mathrm{N}=35 ; \mathrm{ASV} \\
\text { (ACMV), } \mathrm{n}=18 \\
\text { versus CPAP, } \\
\mathrm{n}=17\end{array}$ & $65.5 \pm 9.7$ & CHF with CSA & $\begin{array}{l}\text { AHI, obstructive } \\
\text { and central; } \\
\text { ejection fraction; } \\
\text { ESS }\end{array}$ & $\mathrm{RCT}$ & 4 weeks & NR & 5 & $1+$ & High & $\begin{array}{l}\text { AHI lobstructive and } \\
\text { central) and ejection } \\
\text { fraction improved } \\
\text { significantly more or only } \\
\text { with ASV/ACMV versus } \\
\text { CPAP }\end{array}$ \\
\hline TROUSSIERE [58] & $\begin{array}{l}\mathrm{N}=23 ; \mathrm{CPAP}, \\
\mathrm{n}=14 ; \mathrm{no} \\
\text { treatment, } \mathrm{n}=9\end{array}$ & $\geqslant 65$ & $A D+O S A$ & MMSE & OS & 18 months & $N R$ & 1 & $2-$ & Low & $\begin{array}{c}\text { MMSE decline significantly } \\
\text { slower in CPAP versus no } \\
\text { treatment }\end{array}$ \\
\hline KNAPP [59] & $N=35$ & 65.4 & $\begin{array}{l}\text { Male OSA } \\
\text { patients }\end{array}$ & $\begin{array}{l}\text { Testosterone } \\
\text { levels, SHIM }\end{array}$ & OS & 3 months. & NR & 1 & $2-$ & Low & $\begin{array}{c}\text { No change in testosterone } \\
\text { levels, significant } \\
\text { improvement in SHIM }\end{array}$ \\
\hline NishiHata [60] & $\begin{array}{c}\mathrm{N}=130 ; \mathrm{CPAP} \\
\mathrm{n}=64 ; \mathrm{no} \\
\text { CPAP, } \mathrm{n}=66\end{array}$ & $>65$ (range 65-86) & $\begin{array}{l}\text { Male and female } \\
\text { OSA patients with } \\
\text { history of CVD }\end{array}$ & $\begin{array}{l}\text { Survival rate and } \\
\text { hospitalisation } \\
\text { rate }\end{array}$ & $\cos$ & 32.9 months & $N R$ & 0 & $2-$ & Low & $\begin{array}{l}\text { Survival and hospitalisation } \\
\text { rates were significantly } \\
\text { lower in the CPAP group }\end{array}$ \\
\hline MaRTínez-García [61] & $\begin{array}{c}\text { CPAP, } n=115 \\
\text { no CPAP, } \\
n=109\end{array}$ & $\geqslant 70$ & $\begin{array}{l}\text { Male and female } \\
\text { OSA patients with } \\
A H I \geqslant 30 \text { events } \\
\text { per } \mathrm{h}\end{array}$ & $\begin{array}{c}\text { QOL, cognition, } \\
\text { depression, } \\
\text { anxiety, } \\
\text { office-based BP }\end{array}$ & $\mathrm{RCT}$ & 3 months & $\begin{array}{c}\text { Mean } 4.9 \mathrm{~h} \text { per } \\
\text { night, } 70 \%>4 \mathrm{~h} \\
\text { per night }\end{array}$ & 3 & $1+$ & High & $\begin{array}{l}\text { CPAP associated with } \\
\text { improvement in QOL, } \\
\text { anxiety, depression and } \\
\text { measures of cognition; } \\
\text { no change in BP }\end{array}$ \\
\hline \multicolumn{12}{|c|}{$\begin{array}{l}\text { GRADE: Grading of Recommendations Assessment, Development and Evaluation; CPAP: continuous positive airway pressure; OSA: obstructive sleep apnoea; AHI: apnoea-hypopnoea } \\
\text { index; AD: Alzheimer's disease; RCT: randomised controlled trial; CSA: central sleep apnoea; NR: not reported; LVEF: left ventricular ejection fraction; BiPAP: bilevel positive airway } \\
\text { pressure; CHF: chronic heart failure; CSR: Cheyne-Stokes respiration; COS: cohort study; TIA: transient ischaemic attack; NIH: National Institutes of Health; ESS: Epworth Sleepiness } \\
\text { Scale; LVHF: left ventricular heart failure; BNP: brain natriuretic peptide; ASV: adaptive servoventilation; eGFR: estimated glomerular filtration rate; T30: arterial oxygen saturation <90\% } \\
\text { for } \geqslant 30 \% \text { of total sleep time; } P \mathrm{aO}_{2} \text { : arterial oxygen tension; } \mathrm{PaCO}_{2} \text { : arterial carbon dioxide tension; PD: Parkinson's disease; PSG: polysomnography; N: non-rapid eye movement sleep; R: } \\
\text { rapid eye movement sleep; MSLT: multiple sleep latency test; OS: uncontrolled study; SAQLI: Sleep Apnea Quality of Life Index; BSC: best supportive care; ACMV: anticyclic modulated } \\
\text { ventilation; MMSE: mini-Mental Status Examination; SHIM: Sexual Health Inventory for Men; CVD: cardiovascular disease; BP: blood pressure; QOL: quality of life. \#: see table 1. }\end{array}$} \\
\hline
\end{tabular}


were RCTs with untreated participants as the control groups [38, 46]. For those studies with stroke or vascular events as the outcome, all showed fewer events in the PAP-treated group. The one study examining the effect of PAP on apnoea-related symptoms in stroke patients found no improvement [43].

\section{Dementia}

Seven studies included patients with either Alzheimer's disease [33, 36, 39, 40, 41, 58] or Parkinson's disease [58] and three of these examined the effect of PAP on cognition [33, 41, 58]. The results suggested that PAP treatment in patients with Alzheimer's or Parkinson's disease results in good adherence (see Adherence section later), reduced apnoea-related symptoms (daytime sleepiness) and AHI, and led to deeper sleep [33, 38, 43, 46]. One study found that 3 weeks of PAP treatment resulted in some improvement in cognition, but a 3-week comparison to sham CPAP was underpowered [33]. Two showed that long-term use of PAP in Alzheimer's disease patients resulted in slower cognitive deterioration [41, 58].

\section{Effect on sleep apnoea}

Nine studies either focused on the effect of PAP on OSA-related symptoms (daytime sleepiness and oxygenation) and AHI or included these outcomes as part of their studies [35, 37-40,43,48, 57, 61]. Of these nine, eight were RCTs and one was a controlled open study without randomisation. Seven of the nine studies showed that PAP treatment of OSA resulted in improvement of breathing or of sleep architecture and daytime sleepiness $[35,37,38,39-41,61]$. One study found that there were no significant improvements in any of the outcome measures including daytime sleepiness [43].

\section{Adherence}

Five studies focused on PAP adherence $[41,51,52,54,61]$. An additional four studies reported adherence although it was not an outcome variable $[37,38,43,56]$. Of these nine studies, five were RCTs. Only three studies actually reported hours of PAP use $[36,56,61]$, and this included one in patients with Alzheimer's disease who wore the PAP mask for an average of $4.8 \mathrm{~h}$ [36]. These authors also found that more depressive symptoms were associated with worse adherence [36]. In six articles, the authors all reported that adherence was high and was often associated with greater improvement in the outcome measures but did not report actual hours of use. One study reported more modest usage (medians of $1 \mathrm{~h} 52 \mathrm{~min}$ to $2 \mathrm{~h}$ $22 \mathrm{~min}$ ) but did not correlate the results with outcomes [61]. One study reported that acceptance rates were lower in older patients than younger patients, but there was no difference in the number of hours used within compliers [51].

Mood

Five studies examined the effect of PAP treatment on mood or depression, all of which were RCTs [36, 41, $43,61,55]$ but two were from the same population of subjects (acute versus long-term use of PAP) [36, 41]. Both these studies showed improvement in mood with short- and long-term use. One study found no change in depression scores with PAP use [43] but another did [61].

\section{Cognitive function in elderly patients without dementia}

The PREDICT multicenter study reported that a lower daytime sleepiness score and reduced risk factors for cardiovascular diseases in elderly CPAP users was acheived at the same cost as best supportive care; however, neither CPAP nor best supportive care had an influence on mood or cognitive function [55]. In contrast, the PROOF (Prognostic Indicator of Cardiovascular and Cerebrovascular Events) study found a significant improvement in cognitive function (assessed with different memory tests) after CPAP therapy in OSA patients with no Alzheimer's or Parkinson's disease [56]. The recent RCT from the Spanish Sleep Network noted evidence of improvement in neuropsychological functions on several different measures of cognition [61].

\section{Quality of life and cost effectiveness}

Four studies had quality of life as one of main outcomes of PAP therapy in elderly patients [53, 54, 59, 61]. One of the studies used the Sleep Apnea Quality of Life Index and found a significantly better quality of life in the $21 \%$ who used CPAP [54]. Another study reported substantial effect size differences in all quality of life measures over time in a CPAP group realtive to controls [61]. One study was gender oriented and concentrated on sexual function and male health in older men with OSA [59]. The authors found a better subjective male health quality in the CPAP users versus a control group without CPAP, and this result was independent of testosterone levels.

\section{Summary}

Studies of PAP treatment of SDB in the elderly primarily showed improvement in variables of SDB (e.g. AHI and daytime sleepiness) as well as consequences of SDB including comorbidites and psychosocial 
factors. While studies of the frail elderly (i.e. those with Alzheimer's or Parkinson's disease) were well controlled, the majority came from the same laboratory and the Alzheimer's disease studies were primarily from the same cohort; therefore, replications are needed. In addition, many of the studies had small sample sizes and did not have high evidence levels. Larger, randomised, controlled studies are still needed in older adults and the frail elderly.

\section{Recommendations on the expert consensus level}

1) PAP should be used routinely for the treatment of SDB in older persons and in the frail elderly, particularly those with stroke but without major heart failure with an ejection fraction $\leqslant 45 \%$ (GRADE: strong).

2) While additional RCTs are needed in patients with Alzheimer's or Parkinson's disease, as well as other frail elderly, these patients do tolerate PAP and treatment should be considered (GRADE: strong).

3) PAP leads to a significant improvement of oxygenation in patients with SDB and COPD (overlap syndrome), and should be routinely used in these patients. More studies are needed if additional oxygen further improves results (GRADE: weak).

4) Due to the results of the large RCT SERVE-HF, and the recommendations of all major pulmonary and sleep societies to abstain from servoventilation treatment in patients with heart failure (New York Heart Association functional class 2-4) with an ejection fraction $\leqslant 45 \%$, no recommendation can be given regarding PAP treatment for this patient group until further trials have shown that CPAP, in comparison to servoventilation, has no negative outcome on mortality.

\section{Dental treatment}

Four articles met the inclusion criteria and were reviewed and evaluated. All four had an evidence level of $2-$ and are presented in table 4. Only one of these articles had oral appliance treatment as its topic and this study also stratified results of a larger cohort for age. Three articles assessed denture wearing at night and all three had an elderly patient group; one stratified by age.

\section{Oral appliance treatment}

Currently, the primary treatment for OSA is PAP; however, some patients are unable to tolerate and comply with PAP on a long-term basis. Oral appliances are now widely used for the treatment of snoring and mild-to-moderate OSA as primary therapy, and for severe OSA as an alternative for patients who are unwilling or unable to tolerate PAP [66].

Oral appliances can be divided into two major types: 1) those that reposition the mandible forward, the mandibular advancement splints (MASs) or mandibular advancement device (MADs); and 2) those that hold the tongue forward, the tongue-retaining devices (TRDs) [67]. In a recent review, a RCT comparing MAS to PAP treatment confirmed that PAP is superior in reducing the AHI [68]. Despite the greater efficacy of PAP in the reduction of apnoea, both treatments equally improved quality of life, neuropsychological measurements, cardiovascular disease markers and mortality rate [69-71]. This comparable effectiveness of PAP and MAS has been hypothesised to be related to a greater adherence to MAS when compared to CPAP.

Despite having currently more than 11 RCTs comparing MAS to CPAP, a vast literature on MAS efficacy, and many studies including patients older than 65 years in their sample, there is only one study, to our knowledge, that has evaluated this type of treatment separately for the elderly population. MARKLUND and FrankLIN [65] described, in a retrospective study, the follow-up of 33 patients older than 65 years (mean age $68.5 \pm 1.7$ years) with and without the use of a MAS. They found a statistically significant improvement in the AHI for the group using a MAS (AHI 22.3 \pm 16.7 at baseline and $10.4 \pm 12.9$ with MAS).

While MASs show an overall 50-60\% chance of being able to reduce the AHI to normal levels [72], there are various studies attempting to identify predictors of success. While some studies found that an increase in age was negative predictor of MAS success (i.e. the older the patient the less likely to achieve treatment success), these studies have mainly assessed patients with an average age of 44-49 years of age [68, 73-77]. One study, which included about 5\% patients over the age of 65 years, did not find age to be a predictor of treatment success in either men or women [78]. There is, therefore, a lack of studies focusing on this population and further studies are required to assure the efficacy of MASs for the elderly population.

Another important point in the utilisation of MAS is that there is a need for a minimum of 8-10 teeth per arch and good/constant dental hygiene, and these characteristics are not always the case in the elder and/ or frail population. In these cases, the oral appliance of choice is the TRD. This appliance can be used over 
TABLE 4 Studies evaluating dental treatment in elderly and frail elderly adults

\begin{tabular}{|c|c|c|c|c|c|c|c|c|c|c|}
\hline First author [ref.] & Participants & $\begin{array}{l}\text { Age years } \\
\text { mean }\end{array}$ & $\begin{array}{c}\text { Participant } \\
\text { characteristics }\end{array}$ & Main outcomes & Type of study & $\begin{array}{l}\text { Treatment } \\
\text { duration }\end{array}$ & $\begin{array}{l}\text { Jadad } \\
\text { score }\end{array}$ & $\begin{array}{l}\text { Evidence } \\
\text { level }^{\#}\end{array}$ & $\begin{array}{l}\text { GRADE } \\
\text { level }\end{array}$ & Study conclusions \\
\hline \multicolumn{11}{|c|}{$\begin{array}{l}\text { Nightly denture wearing in } \\
\text { edentulous patients }\end{array}$} \\
\hline Bucca [62] & 48 & 69 & Edentulous & $\begin{array}{l}\mathrm{AHI} \text { with and } \\
\text { without dentures }\end{array}$ & $\cos$ & 1 day & 0 & $2-$ & Low & $\begin{array}{l}\text { Edentulism favors upper } \\
\text { airway obstruction during } \\
\text { sleep; sleep apnoea } \\
\text { significantly worse in the } \\
\text { nights slept without } \\
\text { dentures than in the night } \\
\text { slept with dentures }\end{array}$ \\
\hline ARISAKA [63] & 34 & 72.5 & Edentulous & $\begin{array}{l}\text { AHI with and } \\
\text { without dentures }\end{array}$ & $\cos$ & 1 day & 0 & $2-$ & Low & $\begin{array}{c}\text { Wearing complete } \\
\text { dentures during sleep } \\
\text { improves the AHI of most } \\
\text { edentulous OSAS patients }\end{array}$ \\
\hline ALmeida [64] & 23 & 69.6 & Edentulous & $\begin{array}{c}\mathrm{AHI} \text { and ESS } \\
\text { with and without } \\
\text { dentures }\end{array}$ & $\cos$ & 15 days & 0 & $2-$ & Low & $\begin{array}{l}\text { In mild OSAS patients, the } \\
\text { use of dentures } \\
\text { substantially increases the } \\
\mathrm{AHI} \text {, especially when in the } \\
\text { supine position }\end{array}$ \\
\hline \multicolumn{11}{|c|}{ MAD/oral appliance treatment } \\
\hline MARKLUND [65] & 33 & 68.5 & OSA patients & $\mathrm{AHI}$ and $\mathrm{ESS}$ & $\cos$ & 1 year & 0 & $2-$ & Low & $\begin{array}{l}\text { Elders can be treated } \\
\text { successfully with MADs }\end{array}$ \\
\hline
\end{tabular}


dentures and/or remaining teeth. Still there is a need for manual coordination and probably the lack of tongue tremor to ascertain the proper insertion and retention of the TRD every night. One study comparing the TRD to MAS found similar efficacy but a higher adherence rate to MAS over TRD on dentate subjects (non-denture user) [79]. Previous studies also found similar TRD efficacy. Interestingly these studies mostly assessed dentate individuals younger than 65 years of age [80-83]. The literature on TRD is limited and none of the studies assessed this type of treatment for the elderly or edentulous population.

\section{Denture wearing at night}

The incidence of edentulism (loss of teeth or no teeth) has dropped over the past decades, with a $10 \%$ decline in every decade. Despite this decline, it has been estimated that $24 \%$ of individuals aged $55-$ 65 years will need one or two dentures in 2020, while $28 \%$ of adults between 65 and 75 years, and $41.5 \%$ older than 75 years will need denture services in 2020 in the USA [84]. Tsuda et al. [85], using the Berlin questionnaire, found that $42 \%$ of patients from an edentulous clinic showed a high probability of having OSA. Case reports also suggest edentulism as an OSA risk factor [86].

Dentists generally recommend the removal of dentures during sleep because constant wear is believed, though with little long-term scientific evidence, to increase denture irritation, stomatitis and bone resorption. Bucca et al. [62] therefore assessed the impact of wearing dentures during sleep on two consecutive nights in 48 patients. They found that $48 \%$ of patients had OSA while wearing their dentures during sleep and this incidence rose to $71 \%$ if the individuals removed their denture to sleep. Similarly, ARISAKA et al. [63] found that wearing dentures during sleep improved the apnoeas and hypopneas in $70 \%$ of individuals but interestingly, $14 \%$ showed a significant increase in the AHI while wearing dentures. This controversial aspect was confirmed by AlmEIDA et al. [64], who conducted a randomised trial and found an aggravation of OSA while wearing dentures. This worsening of OSA was predominantly related to individuals with mild OSA sleeping in the supine position [64].

\section{Summary}

Larger RCTs are needed to better understand the role of dentures in the worsening or improvement of OSA. It is important to assess these individuals' characteristics while wearing and not wearing their dentures during PSG. Simple measures, such as sleeping with dentures, may play an important role in improving OSA and decreasing the requirement for treatment of this population.

\section{Recommendations on the expert consensus level}

1) A clear recommendation for MAS, MAD or TRD as first-line treatment in mild-to-moderate SDB can not be given at this point in time as only one study stratified the particiants by age. Further prospective clinical trials with higher evidence levels are needed in the elderly with SDB.

2) In cases of CPAP failure, MAS, MAD or TRD treatment is recommended in elderly SDB patients as second-line treatment after full assessment of a dental status (GRADE: weak).

3) A recommendation for full/partial denture wear at night or non-full/partial denture wear at night in elderly and frail elderly with SDB cannot be given at this point in time as the results of the few clinical trials are too controversial to reach a conclusion.

\section{Cardiac resynchronisation, atrial overpacing, surgical treatment, upper airway stimulation and weight loss}

12 articles for these treatments met the inclusion criteria, were reviewed and evaluated, and are listed in table 5 . Two of these 12 studies (one pacemaker and one bariatric surgery) were stratified for age. The evidence level ranged from $1+$ to $2-$, with six articles about pacemaker therapy having an evidence level of $1+$ (table 5).

\section{Heart pacemakers: cardiac resynchronisation therapy}

Pacemakers are very common in the elderly. 130000 US citizens 65 years and older receive a pacemaker every year. According to a publication by the Grenoble work group, the prevalence of sleep apnoea confirmed by PSG in pacemaker wearers was 59\%, of whom $21 \%$ had severe sleep apnoea defined by an AHI $>40[99,100]$. According to several studies with sufficient evidence levels of 2 or more, cardiac resynchronisation therapy (CRT) with the pacemaker per se reduces apnoeic events by increasing the cardiac output, and reducing atrial afterload and, therefore, periodic breathing. According to a controlled open study with 15 patients, mean age 67 years, CRT reduced apnoeic events and also reduced the increased pulmonary artery pressure [91]. Three trials showed that CRT improves all types of apnoeic 
TABLE 5 Studies evaluating cardiological and surgical treatment in elderly people with sleep breathing disorders

\begin{tabular}{|c|c|c|c|c|c|c|c|c|c|c|}
\hline First author [ref.] & Participants & $\begin{array}{l}\text { Age } \\
\text { years }\end{array}$ & $\begin{array}{c}\text { Participant } \\
\text { characteristics }\end{array}$ & Main outcomes & $\begin{array}{l}\text { Type of } \\
\text { study }\end{array}$ & $\begin{array}{l}\text { Treatment } \\
\text { duration }\end{array}$ & $\begin{array}{l}\text { Jadad } \\
\text { score }\end{array}$ & $\begin{array}{l}\text { Evidence } \\
\text { level }^{\#}\end{array}$ & $\begin{array}{l}\text { GRADE } \\
\text { level }\end{array}$ & Study conclusions \\
\hline \multicolumn{11}{|l|}{$\begin{array}{l}\text { Cardiac } \\
\text { resynchronisation } \\
\text { therapy and atrial } \\
\text { overpacing with } \\
\text { and without CPAP }\end{array}$} \\
\hline BoRDIER [87] & 28 & $\begin{array}{c}\text { Mean } \\
77.9\end{array}$ & $\begin{array}{l}\text { All males with } \\
\text { diagnosed heart } \\
\text { failure and } \\
\text { pacemaker }\end{array}$ & $\begin{array}{l}\mathrm{AHI}, \text { ejection } \\
\text { fraction }\end{array}$ & $\mathrm{RCT}$ & Several days & 2 & $1+$ & High & $\begin{array}{l}\text { Pacemaker overdrive } \\
\text { is favourable over a } \\
\text { low fixed rate in heart } \\
\text { failure patients with } \\
\text { central apnoeas }\end{array}$ \\
\hline SHALABY [88] & 19 & $\begin{array}{c}\text { Mean } \\
68\end{array}$ & $\begin{array}{l}\text { All males with } \\
\text { diagnosed heart } \\
\text { failure, pacemaker } \\
\text { and obstructive } \\
\text { sleep apnoea }\end{array}$ & $\begin{array}{l}\text { AHI, number of } \\
\text { overall apnoeas }\end{array}$ & cos & Several days & 2 & $2+$ & Moderate & $\begin{array}{l}\text { Pacemaker overdrive } \\
\text { is not effective to } \\
\text { reduce apnoeas in } \\
\text { patients with heart } \\
\text { failure and obstructive } \\
\text { sleep apnoea }\end{array}$ \\
\hline SHALABY [89] & 14 & $\begin{array}{c}\text { Mean } \\
66.3\end{array}$ & $\begin{array}{c}\text { Males and females } \\
\text { with heart failure, } \\
\text { pacemaker and } \\
\text { different types of } \\
\text { events }\end{array}$ & $\mathrm{AHI}$ & $\mathrm{RCT}$ & Several days & 3 & $1+$ & High & $\begin{array}{l}\text { Pacemaker overdrive } \\
\text { is not effective to } \\
\text { reduce apnoeas in } \\
\text { patients with heart } \\
\text { failure and apnoeas }\end{array}$ \\
\hline SIMANTIRAKIS [90] & $\begin{array}{c}6 / 16 \\
\text { participants } \\
>65 \text { years of } \\
\text { age }\end{array}$ & $\begin{array}{l}\text { Mean } \\
58.4\end{array}$ & $\begin{array}{c}\text { Males and females } \\
\text { with heart failure, } \\
\text { pacemaker and } \\
\text { different types of } \\
\text { events }\end{array}$ & $\mathrm{AHI}$ & $\mathrm{RCT}$ & Several weeks & 2 & $1+$ & High & $\begin{array}{l}\text { Best treatment to } \\
\text { reduce apnoeas in } \\
\text { patients with heart } \\
\text { failure and pacemaker } \\
\text { is a fixed rate plus } \\
\text { CPAP }\end{array}$ \\
\hline YIU [91] & 15 & $\begin{array}{c}\text { Mean } \\
67.0\end{array}$ & $\begin{array}{l}\text { Males and females } \\
\text { with heart failure, } \\
\text { pacemaker and } \\
\text { different types of } \\
\text { events }\end{array}$ & $\begin{array}{c}\text { AHI, single } \\
\text { events, } \\
\text { pulmonary } \\
\text { artery pressure }\end{array}$ & $\cos$ & Several weeks & 1 & $2+$ & Low & $\begin{array}{l}\text { Pacemaking with a } \\
\text { fixed rate is helpful in } \\
\text { heart failure patients } \\
\text { with central apnoeas }\end{array}$ \\
\hline SHARAFKHANEH [92] & 33 & $\begin{array}{c}\text { Mean } \\
74.0\end{array}$ & $\begin{array}{l}\text { Males and females } \\
\text { with heart failure, } \\
\text { pacemaker and OSA } \\
\text { with } \mathrm{AHI}>15 \text { events } \\
\text { per h, mean ejection } \\
\text { fraction } 38 \%\end{array}$ & $\begin{array}{c}\text { AHI, single } \\
\text { events, ejection } \\
\text { fraction }\end{array}$ & $\mathrm{RCT}$ & 1 night & 3 & $1+$ & High & $\begin{array}{l}\text { Atrial overdrive } \\
\text { pacemaking can } \\
\text { reduce apnoeic events } \\
\text { in heart failure } \\
\text { patients but not on a } \\
\text { significant level } \\
\text { except the patients } \\
\text { are younger than } \\
\sim 70 \text { years of age }\end{array}$ \\
\hline
\end{tabular}




\begin{tabular}{|c|c|c|c|c|c|c|c|c|c|c|}
\hline First author [ref.] & Participants & $\begin{array}{l}\text { Age } \\
\text { years }\end{array}$ & $\begin{array}{c}\text { Participant } \\
\text { characteristics }\end{array}$ & Main outcomes & $\begin{array}{l}\text { Type of } \\
\text { study }\end{array}$ & $\begin{array}{l}\text { Treatment } \\
\text { duration }\end{array}$ & $\begin{array}{l}\text { Jadad } \\
\text { score }\end{array}$ & $\begin{array}{c}\text { Evidence } \\
\text { level }^{\#}\end{array}$ & $\begin{array}{l}\text { GRADE } \\
\text { level }\end{array}$ & Study conclusions \\
\hline KRAHN [93] & $\begin{array}{c}9 / 48 \\
\text { participants } \\
>65 \text { year of age }\end{array}$ & $\begin{array}{l}\text { Mean } \\
54\end{array}$ & $\begin{array}{l}\text { Males and females } \\
\text { with heart failure, } \\
\text { pacemaker and } \\
\text { different types of } \\
\text { events }\end{array}$ & $\begin{array}{l}\text { AHI, single } \\
\text { events }\end{array}$ & $\mathrm{RCT}$ & Several days & 1 & $2+$ & Moderate & $\begin{array}{l}\text { There is no advantage } \\
\text { in overdrive } \\
\text { pacemaking in order } \\
\text { to reduce apnoeas }\end{array}$ \\
\hline PÉPIN [94] & 17 & $\begin{array}{c}\text { Mean } \\
71.0\end{array}$ & $\begin{array}{c}\text { Males and females } \\
\text { with pacemaker and } \\
\text { OSA AHI }>15 \text { events } \\
\text { per } h\end{array}$ & $\begin{array}{l}\text { Atrial overpacing } \\
\text { does not reduce } \\
\text { obstructive } \\
\text { events }\end{array}$ & $\mathrm{RCT}$ & Several days & 3 & $1+$ & High & $\begin{array}{l}\text { OSA in patients with } \\
\text { pacemaker can not be } \\
\text { approved by atrial } \\
\text { overpacing }\end{array}$ \\
\hline LÜTHJE [95] & 30 & $\begin{array}{l}\text { Mean } \\
67.0\end{array}$ & $\begin{array}{c}\text { Males and females } \\
\text { with heart failure, } \\
\text { pacemaker and } \\
\text { different types of } \\
\text { events }\end{array}$ & $\begin{array}{l}\text { Atrial overpacing } \\
\text { showed } \\
\text { significant } \\
\text { reduction of } \\
\text { central and } \\
\text { obstructive } \\
\text { events without } \\
\text { altering sleep } \\
\text { stages }\end{array}$ & $\mathrm{RCT}$ & Several days & 0 & $1+$ & Moderate & $\begin{array}{l}\text { Atrial overpacing is } \\
\text { helpful for both types } \\
\text { of events in heart } \\
\text { failure patients }\end{array}$ \\
\hline \multicolumn{11}{|l|}{ Surgical treatment } \\
\hline BusetTo [96] & $\begin{array}{c}216>65 \text { years } \\
\text { of age } \\
\text { (184 female) }\end{array}$ & $\geqslant 65$ & $\begin{array}{c}\text { Severely obese } \\
\text { patients of all ages, } \\
\text { the elderly was a } \\
\text { subgroup }\end{array}$ & $\begin{array}{l}\text { Of those elderly, } \\
\text { who had OSA } \\
\text { gastric banding } \\
\text { improved AHI in } \\
\text { all cases } \\
<10 \text { events per } \mathrm{h}\end{array}$ & OS & NR & 0 & $2-$ & Low & $\begin{array}{l}\text { Weight loss through } \\
\text { gastric banding in an } \\
\text { obese elderly } \\
\text { population is a } \\
\text { treatment alternative }\end{array}$ \\
\hline Thereaux [107] & $\begin{array}{c}48 \text { older } \\
\text { patients } \\
>60 \text { years of } \\
\text { age, } 680 \\
\text { younger } \\
\text { patients } \\
<60 \text { years }\end{array}$ & $\begin{array}{l}\geqslant 60 \\
\text { mean } \\
63\end{array}$ & $\begin{array}{l}\mathrm{BMI}>45 \mathrm{~kg} \cdot \mathrm{m}^{-2}, \\
\text { Diabetes type II }\end{array}$ & $\begin{array}{l}\text { BMI, weight, } \\
\text { AHI, serum } \\
\text { lipids }\end{array}$ & cos & NR & 0 & $2+$ & Low & $\begin{array}{l}\text { LRYGB is feasible in } \\
\text { older patients and } \\
\text { reduces BMI and AHI } \\
\text { in patients with sleep } \\
\text { apnoea but not with } \\
\text { the same amount as } \\
\text { in younger patients. }\end{array}$ \\
\hline VANOMMESLAEGHE [98] & $\begin{array}{c}250 \text { patients } \\
>60 \text { years } \\
\text { of age }\end{array}$ & $\begin{array}{l}\geqslant 60 ; \\
\text { mean } \\
64.1 \\
\text { (range } \\
60-78 \text { ) }\end{array}$ & $\begin{array}{c}\text { Mean BMI } \\
41.9 \mathrm{~kg} \cdot \mathrm{m}^{-2} \\
\text { multimorbid with } \\
\text { diabetes, sleep } \\
\text { apnoea and } \\
\text { hypertension }\end{array}$ & $\begin{array}{l}\text { BMI, blood } \\
\text { pressure, AHI, } \\
\text { blood sugar } \\
\text { levels }\end{array}$ & cos & NR & 0 & $2+$ & Low & $\begin{array}{l}\text { LRYGB improved all } \\
\text { comorbidities to } \\
\text { severe obesity withou } \\
\text { major operation } \\
\text { complications }\end{array}$ \\
\hline
\end{tabular}


events significantly. In all these trials, CRT was also compared to atrial overpacing in a cross-over fashion $[90,92,95]$.

\section{Atrial overpacing}

The physiological concept behind putting the pacemaker on a higher frequency (overpacing) than with CRT is that the total stroke volume, over time, increases further and, therefore, the atrial afterload is even lower, leading to a further decrease in apnoeas. A recent randomised cross-over trial showed in 28 patients with a mean age of 77.9 years that an overpacing of 20 beats per min over the sensored mean heart rate resulted in a significant reduction of central events [87] (table 5). The only age-stratified study compared CRT and atrial overpacing (AOP) in 15 subjects (mean age 74 years), and found that AOP resulted in a higher reduction of all apnoea events, but not hypopneas, compared to a lower fixed heart rate (mean apnoea index 18 with AOP versus 24 with fixed lower rate coming from a mean baseline of 35 events per h). The age stratification showed a stronger effect at lower ages [92].

Only two trials claimed that CRT and AOP reduced both central and obstructive events, with slight favour towards AOP [92, 95], but several studies with sufficient evidence levels had contrary results [89, 90, 93]. All the studies had a small number of total subjects and often fewer than 10 patients aged over 65 years. The only study with a larger number of patients and all patients aged over 65 years suggested a positive effect of AOP on central, but not obstructive, events [93].

Two studies specifically investigated obstructive events and OSAS. Both with fewer than 20 patients, they found that AOP had no effect on obstructive events [88, 94]. Because of the high prevalence of pacemaker implementation in the higher age group, there is a higher number of publications meeting basic criteria and higher evidence levels in comparison to the overall role this form of treatment plays in SDB treatment. This has to be taken into account when interpreting the following recommendations on the expert consensus level.

\section{Surgical ear, nose and throat procedures/upper airway stimulation}

Among the 1740 articles screened, there were no articles meeting the inclusion criteria. This might be related to avoidance of elderly patients who might have a higher peri- and post-operational risk, as well as to a more sophisticated selection process in order to achieve higher success rates and better long-term results of surgical treatment for OSA and heavy snoring. A good example for this is the actual hypoglossal nerve stimulation (HNS) study of the Stimulation Treatment for Apnea Reduction (STAR) trial, where selection criteria for younger, nonobese OSA patients without concentric collapse in the velopharynx have been set at the highest level to avoid failure of the trial, as has happened in other HNS trials [101]. Fewer than a handful of patients in the STAR trial were over 65 years old.

\section{Surgical treatment for weight loss}

One article met the inclusion criteria of age stratification. This study looked retrospectively into a group of 5290 severely obese subjects with OSA, all of whom received surgery with gastric banding for weight loss. The authors claimed that in the 216 geriatric patients (184 females) aged older than 65 years of the 5290 patients total, the operation was successful in all, bringing the AHI below 10 events per $\mathrm{h}$ [96]. The retrospective analysis has a lower evidence level and the results should be replicated in prospective trials before a statement can be made regarding gastric banding surgery in geriatric patients with SDB. Two articles just missed the inclusion criteria but dealt specifically with an older patient group ( $>60$ years) and had a higher evidence level $[97,98]$. In both, the effects of weight loss after laparoscopic Roux-en-Y gastric bypass (LRYGB) was evaluated in the older patient group, all of whom had been severely obese before surgery. A total of 300 patients had a reduction of their sleep apnoea, AHI and further comorbidities related to their severe obesity without major peri-operative complications. LRYGB has opened the possibility of bariatric surgery for older, severely obese persons, for whom more invasive bariatric surgery has previously posed too great a risk. LRYGB might become a major supportive treatment for all comorbidities of obesity including SDB in the near future.

\section{Dietetic weight loss treatment}

None of the screened publications on dietetic weight loss therapy for SDB treatment met inclusion criteria. Therefore, no statement can be made.

\section{Recommendations on the expert consensus level}

1) In patients with heart failure, atrial fibrillation and central apnoeas, there is evidence that pacemaker implementation can alleviate central apnoeas and periodic breathing. In such patients, pacemaker implementation can be recommended on an expert consensus level (GRADE: strong). 
2) The evidence level is too low to give a recommendation in regard to favouring the type of pacemaker mode. Larger, randomised, controlled cross-over trials are needed in the future to make a statement.

3) No surgical ear, nose and throat procedure can be recommended at this time as therapy for geriatric and frail geriatric patients with OSA, as there is no evidence of success in elderly patient groups. Larger trials in the future should include age stratification (GRADE: weak).

4) Due to new noninvasive surgical methods with laparoscopic LRYGB, for which several-year outcome data show some evidence of clinical success in older patients, this form of bariatric surgery can be considered as supportive treatment in multimorbid (not only sleep apnoea), severely obese patients (body mass index $>40 \mathrm{~kg} \cdot \mathrm{m}^{-2}$ ) in the intermediate elderly age group between 60 and 70 years with SDB. PAP and other treatments should be adapted to the post-operative status (GRADE: weak).

\section{Positional treatment and drug therapy}

Two articles on positional treatment and seven on drug treatment met the inclusion criteria, and were reviewed and evaluated. They are presented in table 6 . The evidence levels ranged from $1+$ to 3 with two RCT drug trials reaching $1+$. One of the drug studies was designed as a negative study and was age stratified.

\section{Positional therapy}

The severity of sleep-related breathing disorders may vary considerably from night to night depending on body position $[112,113]$, although some data have suggested night-to-night variability in elderly persons occurs independently of position [114]. In particular, the supine body position is associated with a two-fold or greater increase in the number of respiratory events in those patients with position-dependent sleep apnoea. Positional therapy includes a wide range of methods aimed at preventing the patient from sleeping in the supine position, including pillows, vests, tennis balls and positional alarms. Case reports have documented the potential utility of positional therapy [112].

Positional therapy has been included in the recent clinical guideline for the treatment of OSA by the Adult Obstructive Sleep Apnea Task Force of the AASM [115]. The guideline identified positional therapy as an effective secondary therapy or a supplement to primary therapies for patients with OSA that have a low AHI in the nonsupine position. Nevertheless, two recent reviews of positional therapies highlighted the fact that long-term compliance for positional therapy remains an issue [116] and that more high-quality research is needed to evaluate the effectiveness of this therapy [117].

One study described one night's use of a specifically designed pillow to avoid the supine position in 22 patients, nine of whom were older than 65 years [102]. This study compared nocturnal respiratory parameters between a baseline night and a night with the supine-avoiding pillow in patients with mild-to-severe OSA. The individual subjects' data are given in a table, which allowed us to identify the nine patients who were between 67 and 73 years old. In these older patients, the respiratory disturbance index decreased from a mean \pm SD of $20 \pm 9$ to $7 \pm 4$ events per $\mathrm{h}$ and minimum arterial oxygen saturation $\left(\mathrm{SaO}_{2}\right)$ during the night rose from $85 \pm 7 \%$ to $89 \pm 4 \%$.

Another study that did not meet the inclusion criteria, but did evaluate the use of a vest for one night in 12 patients between 37 and 76 years of age with in-patients with positional OSA [118]. Although the authors did not stratify by age, they did report that the eldest patient did not improve with this treatment.

In contrast, two recently published studies showed a significant effect of positional therapy with the new sleep position trainer in subjects of all ages. They included several patients $>65$ years of age, but the average age was around 50 years and therefore did not meet inclusion criteria. There was no stratification for age $[119,120]$.

\section{Drug therapy}

There has been no drug therapy recommended for the treatment of SDB. For the treatment of CSA, recent, evidence-based guidelines found limited supporting evidence for acetazolamide and theophyilline after optimisation of standard medical therapy, and if PAP therapy is not tolerated [121]. In addition, the guideline stated that zolpidem and triazolam may be considered for the treatment of primary central apnoea only if the patient does not have underlying risk factors for respiratory depression.

For the treatment of OSA, the 2006 practice parameters for medical treatment of OSA evaluated but did not recommend selective serotonin uptake inhibitors (SSRIs), protriptyline, aminophylline, theophylline or oestrogen therapy based on the lack of sufficient treatment efficacy for OSA [122]. While short-acting nasal decongestants were not recommended, the guidelines concluded that topical nasal corticosteroids may be a useful adjunct to primary therapies in OSA patients with concurrent rhinitis. In addition, modafinil was recommended for the treatment of residual excessive daytime sleepiness in patients with 
TABLE 6 Studies evaluating positional treatment, drug treatment and supplemental oxygen treatment for sleep apnoea in the elderly

\begin{tabular}{|c|c|c|c|c|c|c|c|c|c|c|c|}
\hline First author [ref.] & Participants & Age years & $\begin{array}{c}\text { Participant } \\
\text { characteristics }\end{array}$ & $\begin{array}{c}\text { Main } \\
\text { outcomes }\end{array}$ & $\begin{array}{l}\text { Type of } \\
\text { study }\end{array}$ & Treatment/duration & Compliance & $\begin{array}{l}\text { Jadad } \\
\text { score }\end{array}$ & $\begin{array}{l}\text { Evidence } \\
\text { level }^{\#}\end{array}$ & $\begin{array}{l}\text { GRADE } \\
\text { level }\end{array}$ & Study conclusions \\
\hline \multicolumn{12}{|l|}{ Positional treatment } \\
\hline ZUBERI [102] & 9ा & $\begin{array}{c}\text { Range 67- } \\
73\end{array}$ & $\begin{array}{c}\text { OSAS (RDI } \\
>5 \text { events per } h \text { ) }\end{array}$ & RDI & $\mathrm{OL}$ & 1 night & NR & 0 & 3 & $\begin{array}{l}\text { Very } \\
\text { low }\end{array}$ & $\begin{array}{c}\text { Positional therapy } \\
\text { decreases RDI }\end{array}$ \\
\hline \multicolumn{12}{|c|}{$\begin{array}{l}\text { Drug treatment for central } \\
\text { sleep apnoea }\end{array}$} \\
\hline JAVAHERI [103] & 12 & Mean 66 & $\begin{array}{l}\text { Heart failure, } \\
\text { Cheyne-Stokes } \\
\text { respiration and } \\
\text { AHI > } 15 \text { events } \\
\text { per h on PSG }\end{array}$ & $\mathrm{AHI}, \mathrm{CAl}$ & $\mathrm{RCT}$ & $\begin{array}{c}\text { Acetazolamide } \\
\left(3.5 \mathrm{mg} \cdot \mathrm{kg}^{-1}\right) \text { and } \\
\text { potassium chloride } \\
\text { versus placebo/6 nights }\end{array}$ & NR & 4 & $1-$ & High & $\begin{array}{l}\text { Acetazolamide } \\
\text { reduced central sleep } \\
\text { apnoea in patients } \\
\text { with heart failure }\end{array}$ \\
\hline ZILBERMAN [104] & 38 & Mean 76 & $\begin{array}{l}\text { Congestive heart } \\
\text { failure with } \\
\text { anaemia }(\mathrm{Hb} \\
\left.<12 \mathrm{~g} \cdot \mathrm{dL}^{-1}\right)\end{array}$ & $\mathrm{AHI}, \mathrm{CAl}$ & OS & $\begin{array}{l}\text { Subcutaneous EPO } \\
\text { and i.v. iron/3 months }\end{array}$ & NR & 0 & 3 & $\begin{array}{l}\text { Very } \\
\text { low }\end{array}$ & $\begin{array}{l}\text { Correcting anaemia } \\
\text { in patients with heart } \\
\text { failure improved } \\
\text { sleep apnoea }\end{array}$ \\
\hline \multicolumn{12}{|c|}{$\begin{array}{l}\text { Drug treatment obstructive } \\
\text { sleep apnoea }\end{array}$} \\
\hline MoRAes [105] & 23 & Mean 77 & $\begin{array}{l}\text { Alzheimer's } \\
\text { disease, AHI }\end{array}$ & $\mathrm{AHI}$ & $\mathrm{RCT}$ & Donezepil $5 \mathrm{mg} / 3$ months & NR & 5 & $1+$ & High & $\begin{array}{c}\text { Donzepil improved } \\
\text { OSAS }\end{array}$ \\
\hline Gooneratne [106] & 21 & $\begin{array}{l}\text { Mean } 73.6 \\
\text { and } 70.6\end{array}$ & $\begin{array}{l}>5 \text { events per } \mathrm{h} \\
\mathrm{AHI}>5 \text { events } \\
\text { per } \mathrm{h} \text { and } \\
\text { insomnia }\end{array}$ & SOL & $\mathrm{RCT}$ & $\begin{array}{c}8 \mathrm{mg} \text { ramelteon versus } \\
\text { placebo (concomitant } \\
\text { treatment with APAP in } \\
\text { all)/30 days }\end{array}$ & NR & 5 & $1+$ & High & $\begin{array}{l}\text { Ramelteon add-on to } \\
\text { APAP treatment } \\
\text { decreased SOL }\end{array}$ \\
\hline BRUNNER [107] & 10 & Mean 69 & $\begin{array}{c}\text { Stroke, } \\
\text { AHI }>10 \text { events } \\
\text { per h, refusal of } \\
\text { CPAP }\end{array}$ & $\mathrm{AHI}$ & OS & $\begin{array}{c}15 \text { mg mirtazapine/ } \\
52 \text { days }\end{array}$ & NR & 1 & 3 & $\begin{array}{l}\text { Very } \\
\text { low }\end{array}$ & $\begin{array}{l}\text { Mirtazapine had } \\
\text { mixed effects on } \\
\text { OSAS }\end{array}$ \\
\hline CicoLin [108] & 5 & Mean 65.4 & $\begin{array}{c}\text { Suspected OSAS } \\
\text { and ACE inhibitor } \\
\text { intake }\end{array}$ & $\mathrm{AHI}$ & OS & $\begin{array}{l}\text { Discontinuation of ACE } \\
\text { inhibitor treatment, } \\
\text { introduction of diuretic } \\
\text { (hydrochlorothiazide at } \\
25 \mathrm{mg} \text { per day combined } \\
\text { with spironolactone } \\
\text { at } 25 \mathrm{mg} \text { per day)/ } \\
1 \text { month }\end{array}$ & NR & 0 & 3 & $\begin{array}{l}\text { Very } \\
\text { low }\end{array}$ & $\begin{array}{c}\text { Substituting ACE } \\
\text { inhibitor treatment } \\
\text { with diuretic therapy } \\
\text { decreased OSAS in } \\
\text { patients with ACE } \\
\text { inhibitor-induced } \\
\text { cough }\end{array}$ \\
\hline
\end{tabular}




\begin{tabular}{|c|c|c|c|c|c|c|c|c|c|c|c|}
\hline First author [ref.] & Participants & Age years & $\begin{array}{c}\text { Participant } \\
\text { characteristics }\end{array}$ & $\begin{array}{c}\text { Main } \\
\text { outcomes }\end{array}$ & $\begin{array}{l}\text { Type of } \\
\text { study }\end{array}$ & Treatment/duration & Compliance & $\begin{array}{l}\text { Jadad } \\
\text { score }\end{array}$ & $\begin{array}{l}\text { Evidence } \\
\text { level }^{\#}\end{array}$ & $\begin{array}{l}\text { GRADE } \\
\text { level }\end{array}$ & Study conclusions \\
\hline Sun [109] & 25 & $\begin{array}{c}2 \\
>65 \text { years, } \\
11 \\
<65 \text { years }\end{array}$ & $\begin{array}{c}\text { COPD and } \\
\text { overlap patients }\end{array}$ & $\begin{array}{c}\mathrm{AHI}, \text { maximal } \\
\mathrm{SaO}_{2}\end{array}$ & $\cos$ & $\begin{array}{l}\text { Suvorexant } \\
30 \mathrm{mg} \text { for } 4 \text { consecutive } \\
\text { nights in the elderly } \\
\text { group or placebo }\end{array}$ & NR & 0 & 3 & $\begin{array}{l}\text { Very } \\
\text { loew }\end{array}$ & $\begin{array}{l}\text { Survorexant } \\
\text { treatment made no } \\
\text { difference to } \mathrm{SaO}_{2} \text { or } \\
\text { AHI versus placebo }\end{array}$ \\
\hline \multicolumn{12}{|c|}{$\begin{array}{l}\text { Supplemental oxygen } \\
\text { treatment }\end{array}$} \\
\hline FROHNHOFEN [110] & 1 & 92 & $\begin{array}{l}\text { Old frail woman } \\
\text { with Charles } \\
\text { Bonnet sydrome } \\
\text { and OSAS }\end{array}$ & $\begin{array}{l}\text { Hallucinations } \\
\text { stopped }\end{array}$ & $\mathrm{CR}$ & 3 months & NR & 0 & 3 & $\begin{array}{l}\text { Very } \\
\text { low }\end{array}$ & $\begin{array}{l}\text { Oxygen stopped } \\
\text { symptoms of Charles } \\
\text { Bonnet Syndrome }\end{array}$ \\
\hline FROHNHOFEN [111] & 200 & $\begin{array}{c}\text { Mean } \pm \text { SD } \\
82 \pm 6\end{array}$ & $\begin{array}{c}\text { Geriatric, } \\
\text { in-hospital, with } \\
\text { severe SDB ODI } \\
>30 \text { events per h }\end{array}$ & $\begin{array}{l}\text { Functional } \\
\text { status }\end{array}$ & $\cos$ & & $N R$ & 0 & 3 & $\begin{array}{l}\text { Very } \\
\text { low }\end{array}$ & $\begin{array}{l}\text { No treatment versus } \\
\text { CPAP versus oxygen }\end{array}$ \\
\hline
\end{tabular}

GRADE: Grading of Recommendations Assessment, Development and Evaluation; OSAS: obstructive sleep apnoea syndrome; RDI: respiratory disturbance index; OL: open label; NR: not reported; AHI: apnoea-hypopnoea index; PSG: polysomnography; CAl: central apnoea index; RCT: randomised controlled trial; Hb: haemoglobin; OS: uncontrolled study; EPO: erythropoietin; SOL: sleep onset latency; APAP: autotitrating positive airway pressure; CPAP: continuous positive airway pressure; ACE: angiotensin-converting enzyme; COPD: chronic obstructive pulmonary disease; $\mathrm{SaO}_{2}$ : arterial oxygen saturation; CR: case report; SDB: sleep disordered breathing; ODI: oxygen desaturation index; COS: cohort study. \#: see table 1; I: the study included nine patients and presented individual subjects' data for five patients with ACE inhibitor-induced cough and a mean age $>65$ years. 
sleepiness despite effective PAP treatment and without other identifiable causes for the sleepiness. These recommendations concur with the most recent 2009 clinical guideline for the evaluation, management and long-term care of OSA in adults [115].

In 2013, a Cochrane systematic review and meta-analysis on drug therapy for OSA evaluated randomised, placebo-controlled trials involving adult patients with OSA [123]. The review included data of 30 trials evaluating 25 different drugs but noted that most of the studies were small with methodological limitations and that the overall quality of the available evidence was low. The review also concluded that there is currently insufficient evidence to recommend any systematic pharmacological treatment for OSA. Nevertheless, donezepil was identified as the most promising proposition at present and the authors suggested topical fluticasone in patients with co-existing rhinitis, as well as paroxetine, physostigmine, acetazolamide and eszopiclone as possible fields of future research. These studies, however, were not in elderly.

Concerning the treatment of CSA in the elderly, we located one double-blind, randomised cross-over trial that evaluated the use of acetazolamide in patients with systolic heart failure and Cheyne-Stokes breathing with an AHI above 15 events per h [103]. A total of 12 patients with a mean age of 66 years were treated for six nights with placebo or with $3.5-4 \mathrm{mg} \cdot \mathrm{kg}^{-1}$ acetazolamide and $30 \mathrm{mg}$ potassium chloride, with the later given to compensate for acetazolamide-induced urinary potassium loss. Compared to the placebo condition, acetazolamide was associated with a mild-to-moderate reduction of the AHI and the central apnoea index, and an increase in baseline oxygen and minimum saturation during rapid eye movement (REM) and non-REM sleep. Polysomnographic sleep parameters did not differ between acetazolamide and placebo.

A further study evaluated the treatment of anaemia in patients with congestive heart failure and anaemia [104]. In this open-label study, 38 patients with a mean age of 76 years and haemoglobin levels below $12 \mathrm{~g} \cdot \mathrm{dL}^{-1}$ were treated for 3 months with erythropoietin and intravenous iron up to a target level of $13 \mathrm{~g} \cdot \mathrm{dL}^{-1}$. The presence of sleep apnoea was not an inclusion criterion but 37 out of 38 patients had an AHI greater 10 events per h during nocturnal polygraphy, with most of the apnoeas and hypopneas being central. Treatment of anaemia was associated with a mild-to-moderate reduction of sleep-related breathing observed both for central and obstructive apnoeas. In addition, a reduction of Cheyne-Stokes breathing and an increase in minimal oxygen saturation during sleep was noted. Furthermore, daytime sleepiness improved after 3 months.

For the treatment of OSA in elderly subjects, we located one double-blind, randomised, placebo-controlled trial that targeted OSA [105]. In this trial, 23 patients (68-86 years) with mild-to-moderate Alzheimer's disease and $\mathrm{AHI}>5$ events per $\mathrm{h}$ were randomised to receive 3 months of $5 \mathrm{mg}$ donezepil or placebo. Compared to placebo, donezepil treatment improved the overall AHI and minimum oxygen saturation. In addition, REM sleep increased and the arousal index decreased. Finally, cognitive function assessed with the ADAS-cog (Alzheimer Disease Assessment Measures - Cognition) score was improved in the donezepil treated group compared to the placebo group.

A further double-blind, placebo-controlled, randomised trial [106] investigated whether the addition of ramelteon, a melatonin receptor agonist, improved sleep in elderly patients with sleep apnoea and insomnia symptoms. 23 patients (mean ages 74 and 70 years) received a standard 45 min counselling session on sleep apnoea and started auto-PAP (APAP) treatment before being randomised to receive $8 \mathrm{mg}$ of ramelteon $(n=8)$ or matching placebo $(n=15)$ for 4 weeks. Sleep onset latency during PSG was reduced in patients taking ramelteon while neither sleep efficiency, AHI, subjective sleep latency nor sleep efficiency differed between groups subsequent to treatment. In addition, self-rated sleep quality, quality of life and daytime sleepiness were the same for patients treated with ramelteon versus those treated with placebo. In addition, compliance with APAP treatment did not differ between groups and overall APAP adherence defined as $\geqslant 4 \mathrm{~h}$ of use for four or more nights per week was $47 \%$.

Another drug that has been evaluated for the treatment of OSA is mirtazapine, which had shown some effect on sleep-related breathing in randomised trials of adult patients [124]. In a subsequent open-label case series evaluating $15 \mathrm{mg}$ mirtazapine at bedtime for 16-52 days in elderly patients with sleep apnoea and refusal of CPAP reported mixed effects on breathing parameters [107]. While mirtazapine improved sleep-related breathing to some extent in half of the patients, it also worsened sleep-related breathing in the other half of the patients, despite improving sleep in all patients.

Based on the observation of a single case with moderate OSA and suspected angiotensin-converting enzyme (ACE) inhibitor-induced cough with significant improvement of OSA after the ACE inhibitor was withdrawn and diuretics were introduced, a prospective case series included nine patients with suspected OSA and on ACE inhibitor treatment, in whom ACE inhibitors were withdrawn and diuretics were 
introduced (hydrochlorothiazide at $25 \mathrm{mg}$ per day combined with spironolactone at $25 \mathrm{mg}$ per day) [108]. The paper included data on a subgroup of 5 patients with cough that had an average age of 65.4 years and was therefore included in the present review. In these patients, AHI decreased in all and exhaled nitric oxide, a marker of airway inflammation, decreased in parallel after discontinuation of ACE inhibitors.

A recent cross-over study in patients with COPD and overlap syndrome found no negative effects on nightly respiration in regards to $\mathrm{AHI}$ and $\mathrm{SaO}_{2}$ for the use of the orexin receptor antagonist and sleep drug survorexant. This study was age stratified using a different dosage, $30 \mathrm{mg}$, for a patient group $>65$ years of age [109].

Other case reports have suggested value of topiramate, aripiprazole and selenium [125-127] in the treatment of sleep apnoea.

\section{Summary}

Large, controlled studies on drug therapy of sleep-related breathing disorders in the elderly are still lacking. Two drugs that have received support from the results of smaller randomised trials are donezepil for the treatment of OSA and acetazolamide for the treatment of CSA. Both drugs have been shown to be effective in the treatment of sleep-related breathing disorders in an elderly population with mild (acetazolamide) or moderate (donezepil) effects. In addition, there is some indication that improvement of comorbid conditions in elderly patients with sleep-related breathing disorders may also show some benefit for breathing disorders during sleep, as observed for correcting anaemia in patients with CHF and anaemia in an open-label trial.

\section{Recommendations on the expert consensus level}

1) Due to insufficient data, positional treatment cannot be recommended as treatment for OSA in the elderly (GRADE: strong).

2) More research is needed on the long-term effectiveness of drug therapy for the treatment of sleep-related breathing disorders in the elderly. At this point in time, no recommendation for drug therapy to treat SDB in the elderly can be given.

3) Acetazolamide might alleviate Cheynes-Stokes breathing in elderly patients with heart failure but further randomised controlled studies would be needed and side-effects in long-term treatment investigated in order to make recommendations.

4) Drugs used to treat dementia such as donezipil, melatoninergic drugs such as ramelton and agomelatine, and mirtazepin, erythropoietin, ACE inhibitors, and others can help to alleviate clinical symptoms of comorbidities of SDB but can currently not be recommended for the treatment of SDB in the elderly (GRADE: weak).

5) Clinicians should be aware that several drugs may aggrevate sleep apnoea (GRADE: strong).

\section{Supplemental oxygen}

Only two articles (one observational study and one case report, evidence level 3) were identified that fit the selection criteria and addressed the effects of oxygen treatment on functional outcomes in older or frail people with SDB. They are presented in table 6 . None of the studies was age stratified.

Intermittent nocturnal hypoxaemia (INH) is a frequent consequence of both CSA and OSA. INH is associated with cognitive [128-131] and functional [132] impairments. A large epidemiological study showed that INH rather than the number of apnoeic events per se doubled the risk of dementia in previously nondemented, older, community-dwelling persons over a follow up period of 4 years [133]. In a study of geriatric patients admitted for rehabilitation, INH was associated with functional impairment in a dose-response relationship. However, as PSG was not performed, apnoea frequency and sleep fragmentation could not be ruled out as additional factors [134]. Nocturnal hypoxaemia increases sympathetic activity and may contribute to cardiovascular complications of SDB such as hypertension and arrhythmias [135]. Oxygen supplementation might therefore be effective in improving symptoms and complications of sleep apnoea, even if it does not directly address the airway obstruction. At least one case report suggests benefit of nocturnal oxygen administration [110].

One observational study included 200 consecutive geriatric in-patients with severe SDB defined as an oxygen desaturation index $>30$ events per h. Each subject was first offered PAP therapy and then offered nocturnal oxygen therapy at a rate of $3 \mathrm{~L} \cdot \mathrm{min}^{-1}$ via nasal tubes as a second choice if they refused PAP. The mean age was $81 \pm 7$ years. 22 (11\%) patients accepted PAP, 42 (21\%) accepted oxygen supplementation and 136 (68\%) refused either treatment. Baseline functional status (Barthel index) was 48, 39 and 42 for PAP accepters, oxygen accepters and treatment refusers, and improved by 7, 22 and 24 points, respectively, by discharge. There was no difference in the level of improvement between oxygen 
and PAP, and regression analysis showed that oxygen supplementation was independently associated with functional improvement [111].

The information retrieved from this systematic review alone is clearly insufficient to inform guidelines on oxygen treatment in for OSA in the older or frail person. We have therefore also adduced evidence from studies in younger populations and evidence form trials that reported the effect of oxygen on OSA itself, rather than from wider functional outcomes.

A recent meta-analysis of oxygen supplementation in younger and middle-aged subjects with OSA identified 14 RCTs including a total of 359 patients [136]. The sample size of the individual studies included was small, ranging from $n=8$ to $n=63$, and dose and duration of oxygen supplementation varied between studies, making comparisons difficult. Only 10 studies reported the effect of oxygen treatment on the extent and severity of OSA itself, while five also reported functional outcomes (e.g. daytime sleepiness and depression). Oxygen supplementation significantly improved nocturnal oxygen saturation and led to a small but overall nonsignificant reduction in apnoea frequency. However, oxygen supplementation also increased the duration of apnoeas in three out of five observational studies, and in a larger comparison between oxygen versus CPAP with blood pressure as outcome, CPAP had a clear advantage in decreasing blood pressure over oxygen alone [137].

Functional outcomes were reported in five studies. Of these, one showed an improvement of depressive symptoms and sleepiness with oxygen therapy [138], one a reduction in cardiovascular events [139], and two reductions in daytime somnolence $[140,141]$. The largest study, however, showed no improvement of daytime somnolence with oxygen, but significant improvement with PAP [137].

The increase of apnoea duration, even in the absence of hypoxia, can lead to metabolic acidosis and an increase in sympathetic activation [142], which could at least theoretically increase cardiovascular complications. This has not been observed in the meta-analysis or in the two studies in this systematic review, but could be a potential risk. This should be addressed formally in future studies of the effect of oxygen supplementation in OSA in older adults.

\section{Summary}

Oxygen supplementation in subjects with sleep apnoea and intolerance of PAP treatment seems rational, since oxygen supplementation corrects hypoxaemia as well as PAP and has a minor, but nonsignificant, beneficial effect on apnoea frequency. Taking into account the high number of older subjects affected by SBD [4] and the high rate of intolerance of PAP treatment [143], RCTs in community-dwelling and nursing-home older people are warranted. Such trials should assess the effectiveness of oxygen supplementation in older people with sleep apnoea who refuse PAP treatment. They should also include determination of potential metabolic consequences such as acidosis, and functional outcomes such as the ability to perform activities of daily living, cognitive status, quality of life, the frequency of nursing home placement and mortality. Only then can the importance of oxygen therapy be assessed unambiguously. Currently, this therapy should be considered as experimental.

\section{Recommendations on the expert consensus level}

1) Oxygen treatment should not be used routinely for the treatment of OSA in older persons (GRADE: strong).

2) In older, frail or demented patients who refuse PAP, oxygen treatment may be considered but blood gases should be checked to exclude metabolic acidosis (GRADE: weak).

3) RCTs of oxygen treatment in this patient group with functional outcome measures are needed to inform treatment guidelines.

\section{Discussion}

To our knowledge, this is the first systematic review of original studies addressing the treatment of SDB in the elderly. It is also the first publication of an expert consensus on SDB treatment in older or frail patients.

Over the timeframe of almost 12 years, there were surprisingly few studies examining treatment of SDB in older adults and even fewer in frail older adults despite the large geriatric population and the high prevalence for SDB in this group. Studies of the management of OSA in the older patient population are rarely stratified for age. Studies that did include age stratification in SDB treatment mainly focused on the middle-aged and younger patient groups. Had more studies in larger cohorts with a number of older patients included age stratification, a more advanced meta-analysis of data in the elderly would have been possible. Therefore, one recommendation of the panel is to retrospectively age stratify SDB treatment trials and publish this data subset, as in the Swedish oral appliance data set [65]. In addition, new studies 
should also include age stratification in their analyses. Beyond stratification per se, formal analyses should examine to what extend age may be an effect modifier of treatment benefit.

It is unclear why there are so few reports of the treatment of SDB in the geriatric population and why there are few larger RCTs, although there is a large number of epidemiological studies of prevalence of SDB in the elderly. Reasons could include a higher refusal rate for PAP treatment by older persons, perhaps also influenced by views of their younger relatives. However, if an old person does accept PAP, compliance is good. This low rate would result in a lower number of treated older adults being included in studies. Staff in regular sleep laboratories do not specialise in geriatric patients and, therefore, may not be able to cope with the extended nursing needs of the elderly, and especially that frail elderly [4, 19]. Home testing of geriatric patients might make these studies more feasible.

There are still few studies of the frail elderly, even though they most certainly have an even higher prevalence of SDB than younger groups, and might benefit from treatment. Reasons for this have been pinpointed above. More RCTs in geriatric patients with dementia are needed to determine if PAP in patients with dementia improves cognitive function, as in in middle-aged or non-frail older patient populations.

However, in addition to the still limited number of publications to date, it is obvious that the topic of geriatric sleep medicine is gaining more and more attention. The number of articles concerning elderly SDB patients just in the last year has expanded substantially compared to previous years. This also includes articles on therapy of SDB in the frail elderly, as presented here. Further recent epidemiological reports with several hundred elderly subjects combined mainly contain data about the link between SDB in the elderly and a rapid cognitive decline [144-146]. One very recent article encompassing a registry of of $>25000$ OSA patients in Denmark followed up over $>10$ years presented age-stratified data comparing the survival rate of PAP users to OSA patients who were, for various reasons, not treated with PAP [147]. The protective effect of PAP appeared particularly strong in older men $>60$ years of age. Elderly women may not derive comparable benefit from PAP treatment relative to men. The reasons for this sex difference are not yet clear.

A limitation of this expert consensus panel is that clinical recommendations are based on a small number of trials with high evidence levels. In addition, as with all expert panels, personal bias cannot be excluded. Experts from outside the Americas and Europe were not part of the panel. Therefore, the recommendations included here had to reach 100\% agreement among the expert panel. This is the reason that recommendations for the treatment of SDB in geriatric patients at the moment do not differ much from principle of practice parameters for the treatment of SDB in all age groups [148].

In summary, the individual recommendations are listed within each section, but the common theme is that more randomised controlled studies are needed in geriatric and frail elderly patients with SDB, as comparable in other fields of general internal medicine [149].

\section{References}

World Health Organization. Global Health and Aging. Geneva, WHO, 2011.

Young T, Peppard PE, Gottlieb DJ. Epidemiology of obstructive sleep apnea: a population health perspective. Am J Respir Crit Care Med 2002; 165: 1217-1239.

3 Young T, Shahar E, Nieto FJ, et al. Predictors of sleep-disordered breathing in community-dwelling adults: the Sleep Heart Health Study. Arch Intern Med 2002; 162: 893-900.

4 Ancoli-Israel S, Kripke DF, Klauber MR, et al. Sleep-disordered breathing in community-dwelling elderly. Sleep 1991; 14: 486-495.

5 Ancoli-Israel S, Klauber MR, Kripke DF, et al. Sleep apnea in female patients in a nursing home. Increased risk of mortality. Chest 1989; 96: 1054-1058.

Rowe JW, Kahn RL. "Successful Aging”. Gerontologist 1999; 37: 433-440.

Munoz R, Duran-Cantolla J, Martínez-Vila E, et al. Severe sleep apnea and risk of ischemic stroke in the elderly. Stroke 2006; 37: 2317-2321.

8 Muñoz R, Durán-Cantolla J, Martinez-Vila E, et al. Central sleep apnea is associated with increased risk of ischemic stroke in the elderly. Acta Neurol Scand 2012; 126: 183-188.

9 Sahlin C, Sandberg O, Gustafson Y, et al. Obstructive sleep apnea is a risk factor for death in patients with stroke: a 10-year follow-up. Arch Intern Med 2008; 168: 297-301.

10 Onen SH, Lesourd B, Ouchchane L, et al. Occult nighttime hypertension in daytime normotensive older patients with obstructive sleep apnea. J Am Med Dir Assoc 2012; 13: 752-756.

11 Onen SH, Mouriaux F, Berramdane L, et al. High prevalence of sleep-disordered breathing in patients with primary open-angle glaucoma. Acta Ophthalmol Scand 2000; 78: 638-641.

12 Onen F, Higgins S, Onen SH. Falling-asleep-related injured falls in the elderly. J Am Med Dir Assoc 2009; 10: 207-210.

13 Onen F, Onen SH. Fundamentals of quality of life and daytime sleepiness measurements in older sleep apnea patients. Sleep Med 2010; 11: 332.

14 Onen SH, Onen F, Albrand G, et al. Pain tolerance and obstructive sleep apnea in the elderly. J Am Med Dir Assoc 2010; 11: 612-616.

15 Cochen V, Arbus C, Soto ME, et al. Sleep disorders and their impacts on healthy, dependent, and frail older adults. J Nutr Health Aging 2009; 13: 322-329. 
Gooneratne NS, Richards KC, Joffe M, et al. Sleep disordered breathing with excessive daytime sleepiness is a risk factor for mortality in older adults. Sleep 2011; 34: 435-442.

Onen SH, Dauphinot V, Gooneratne NS, et al. Morbidity and predicted mortality in older adults with central sleep apnea. J Sleep Disord Ther 2013; 2: 146.

Tarasiuk A, Greenberg-Dotan S, Simon-Tuval T, et al. The effect of obstructive sleep apnea on morbidity and health care utilization of middle-aged and older adults. J Am Geriatr Soc 2008; 56: 247-254.

Namen AM, Landry SH, Case LD, et al. Sleep histories are seldom documented on a general medical service. South Med J 2001; 94: 874-879.

Netzer NC, Hoegel JJ, Loube D, et al. Prevalence of symptoms and risk of sleep apnea in primary care. Chest 2003; 124: 1406.

Onen SH, Albrand G, Gaujard S, et al. Atypie clinique du syndrome d'apnées du sommeil chez le patient âgé [Atypical clinical sleep apnoea syndrome in the elderly]. Rev Med Intern 2006; 27: Suppl. 3, 289-335.

Onen F, Moreau T, Gooneratne NS, et al. Limits of the Epworth Sleepiness Scale in older adults. Sleep Breath 2013; 17: 343-350.

Onen SH, Dubray C, Decullier E, et al. Observation-based nocturnal sleep inventory: screening tool for sleep apnea in elderly people. J Am Geriatr Soc 2008; 56: 1920-1925.

Soyeux L, Grosjean J, Onen S-H. Troubles respiratoires du sommeil en EHPAD: étude de prévalence réalisée avec l'outil ONSI [Sleep related breathing disorders in nursing home: prevalence study using the ONSI]. Med Sommeil 2012; 9: 11-16.

Giles TL, Lasserson TJ, Smith BH, et al. Continuous positive airways pressure for obstructive sleep apnoea in adults. Cochrane Database Syst Rev 2006; 3: CD001106.

Lin MT, Lin HH, Lee PL, et al. Beneficial effect of continuous positive airway pressure on lipid profiles in obstructive sleep apnea: a meta-analysis. Sleep Breath 2015; 19: 809-817.

Drager LF, Brunoni AR, Jenner R, et al. Effects of CPAP on body weight in patients with obstructive sleep apnoea: a meta-analysis of randomised trials. Thorax 2015; 70: 258-264.

Povitz M, Bolo CE, Heitman SJ, et al. Effect of treatment of obstructive sleep apnea on depressive symptoms: systematic review and meta-analysis. PLoS Med 2014; 11: e1001762.

Sukhal S, Khalid M, Tulaimat A. Effect of wakefulness-promoting agents on sleepiness in patients with sleep apnea treated with CPAP: a meta-analysis. J Clin Sleep Med 2015; 11: 1179-1186.

Guyatt G, Oxman AD, Akl EA, et al. GRADE guidelines: 1. Introduction - GRADE evidence profiles and summary of findings tables. J Clin Epidemiol 2011; 64: 383-394.

Harbour R, Miller J. A new system for grading recommendations in evidence based guidelines. BMJ 2001; 323: 334-336.

Jadad AR, Moore RA, Carroll D, et al. Assessing the quality of reports of randomized clinical trials: is blinding necessary? Control Clin Trials 1996; 17: 1-12.

Ancoli-Israel S, Palmer BW, Cooke JR, et al. Effect of treating sleep disordered breathing on cognitive functioning in patients with Alzheimer's disease: a randomized controlled trial. J Am Geriatr Soc 2008; 56: 2076-2081.

Arzt M, Floras JS, Logan AG, et al. Suppression of central sleep apnea by continuous positive airway pressure and transplant-free survival in heart failure: a post hoc analysis of the Canadian Continuous Positive Airway Pressure for Patients with Central Sleep Apnea and Heart Failure Trial (CANPAP). Circulation 2007; 115: 3173-3180.

Arzt M, Wensel R, Montalvan S, et al. Effects of dynamic bilevel positive airway pressure support on central sleep apnea in men with heart failure. Chest 2008; 134: 61-66.

Ayalon L, Ancoli-Israel S, Stepnowsky C, et al. Adherence in patients with Alzheimer's disease and obstructive sleep apnea. Am J Geriatr Psychiatry 2006; 14: 176-180.

Bravata DM, Concato J, Fried T, et al. Auto-titrating continuous positive airway pressure for patients with acute transient ischemic attack: a randomized feasibility trial. Stroke 2010; 41: 1464-1470.

Bravata DM, Concato J, Fried T, et al. Continuous positive airway pressure: evaluation of a novel therapy for patients with acute ischemic stroke. Sleep 2011; 34: 1271-1277.

Chong MS, Ayalon L, Marler M, et al. Continuous positive airway pressure improves subjective daytime sleepiness in mild-moderate Alzheimer's disease patients with sleep disordered breathing. J Am Geriatr Soc 2006; 54: 777-781.

Cooke JR, Ancoli-Israel S, Liu L, et al. Continuous positive airway pressure deepens sleep in patients with Alzheimer's disease and obstructive sleep apnea. Sleep Med 2009; 10: 1101-1106.

Cooke JR, Palmer BW, Loredo JS, et al. Sustained use of continuous positive airway pressure slows deterioration of cognition, sleep, and mood in patients with Alzheimer's disease and obstructive sleep apnea: An exploratory study. J Clin Sleep Med 2009; 5: 305-310.

Dohi T, Kasai T, Narui K, et al. Bi-level positive airway pressure ventilation for treating heart failure with central sleep apnea that is unresponsive to continuous positive airway pressure. Circ J 2008; 72: 1100-1105.

Hsu CY, Vennelle M, Li HY, et al. Sleep-disordered breathing after stroke: a randomised controlled trial of continuous positive airway pressure. J Neurol Neurosurg Psychiatry 2006; 77: 1143-1149.

Koyama $\mathrm{T}$, Watanabe $\mathrm{H}$, Terada $\mathrm{S}$, et al. Adaptive servo-ventilation improves renal function in patients with heart failure. Respir Med 2011; 105: 1946-1953.

Lacedonia D, Carpagnano GE, Aliani M, et al. Daytime $\mathrm{PaO}_{2}$ in OSAS, COPD and the combination of the two (overlap syndrome). Respir Med 2013; 107: 310-316.

Martínez-García MA, Galiano-Blancart R, Román-Sánchez P, et al. Continuous positive airway pressure treatment in sleep apnea prevents new vascular events after ischemic stroke. Chest 2005; 128: 2123-2129.

Martínez-García MA, Campos-Rodríguez F, Catalán-Serra P, et al. Cardiovascular mortality in obstructive sleep apnea in the elderly: role of long-term continuous positive airway pressure treatment: a prospective observational study. Am J Respir Crit Care Med 2012; 186: 906-916.

Neikrug AB, Liu L, Avanzino JA, et al. Continuous positive airway pressure improves sleep and daytime sleepiness in patients with Parkinson disease and sleep apnea. Sleep 2014; 37: 177-185. 
Randerath WJ, Nothofer G, Priegnitz C, et al. Long-term auto-servoventilation or constant positive pressure in heart failure and coexisting central with obstructive sleep apnea. Chest 2012; 142: 440-447.

Takama N, Kurabayashi M. Effectiveness of adaptive servo-ventilation for treating heart failure regardless of the severity of sleep-disordered breathing. Circulation 2011; 75: 1164-1169.

Yang MC, Lin CY, Lan CC, et al. Factors affecting CPAP acceptance in elderly patients with obstructive sleep apnea in Taiwan. Respir Care 2013; 58: 1504-1513.

Woehrle H, Graml A, Weinreich G. Age- and gender-dependent adherence with continuous positive airway pressure therapy. Sleep Med 2011; 12: 1034-1036.

Yagihara F, Lucchesi LM, D'Almeida V, et al. Oxidative stress and quality of life in elderly patients with obstructive sleep apnea syndrome: are there differences after six months of Continuous Positive Airway Pressure treatment? Clinics (Sao Paulo) 2012; 67: 565-572.

Ng SSS, Chan TO, To KW, et al. Prevalence of obstructive sleep apnea syndrome and CPAP adherence in the elderly Chinese population. PLoS One 2015; 10: e0119829.

McMilan A, Bratton DJ, Faria R, et al. Continous positive airway pressure in older people with obstructive sleep apnoea syndrome (PREDICT): a 12 month multicenter randomized trial. Lancet Respir Med 2014; 2: 804-812.

Crawford-Achour E, Dauphinot V, Martin MS, et al. Protective effect of long-term CPAP therapy on cognitive performance in elderly patients with severe OSA: The PROOF Study. J Clin Sleep Med 2015; 11: 519-524.

Galetke W, Ghassemi BM, Priegnitz C, et al. Anticyclic modulated ventilation versus continuous positive airway pressure in patients with coexisting obstructive sleep apnea and Cheynes-Stokes respiration: a randomized crossover trial. Sleep Med 2014; 15: 874-879.

Troussiere AC, Charley CM, Salleron J, et al. Treatment of sleep apnoea syndrome decreases cognitive decline in patients with Alzheimer's disease. J Neurol Neurosurg Psychiatry 2014; 85: 1405-1408.

Knapp A, Myhill PC, Davis WA, et al. Effect of continuous positive airway pressure therapy on sexual function and serum testosterone in males with type 2 diabetes and obstructive sleep apnoea. Clin Endocrinol (Oxf) 2014; 81: 254-258.

Nishihata Y, Takata Y, Usui Y, et al. Continuous positive airway pressure treatment improves cardiovascular outcomes in elderly patients with cardiovascular disease and obstructive sleep apnea. Heart Vessels 2015; 30: 61-69. Martínez-García MA, Chiner E, Hernandez L, et al. Obstructive sleep apnea in the elderly. Role of continuous positive airway pressure treatment. Eur Respir J 2015; 46: 142-151.

Bucca C, Cicolin A, Brussino L, et al. Tooth loss and obstructive sleep apnoea. Respir Res 2006; 7: 8.

Arisaka H, Sakuraba S, Tamaki K, et al. Effects of wearing complete dentures during sleep on the apnea-hypopnea index. Int J Prosthodont 2009; 22: 173-177.

Almeida FR, Furuyama RJ, Chaccur DC, et al. Complete denture wear during sleep in elderly sleep apnea patients - a preliminary study. Sleep Breath 2012; 16: 855-863.

Marklund M, Franklin KA. Treatment of elderly patients with snoring and obstructive sleep apnea using a mandibular advancement device. Sleep Breath 2015; 19: 403-405.

Kushida CA, Morgenthaler TI, Littner MR, et al. Practice parameters for the treatment of snoring and obstructive sleep apnea with oral appliances: An update for 2005. Sleep 2006; 29: 240-243.

Fleetham JA, Almeida FR. Oral appliances. In: McNicholas WT, Bonsignore MR, eds. Sleep Apnoea (ERS Monograph). Sheffield, European Respiratory Society, 2010; pp. 267-285.

Sutherland K, Vanderveken OM, Tsuda H, et al. Oral appliance treatment for obstructive sleep apnea: an update. J Clin Sleep Med 2014; 10: 215-227.

Mehta A, Qian J, Petocz P, et al. A randomized, controlled study of a mandibular advancement splint for obstructive sleep apnea. Am J Respir Crit Care Med 2001; 163: 1457-1461.

Phillips CL, Grunstein RR, Darendeliler MA, et al. Health outcomes of continuous positive airway pressure versus oral appliance treatment for obstructive sleep apnea: a randomized controlled trial. Am J Respir Crit Care Med 2013; 187: 879-887.

Anandam A, Patil M, Akinnusi M, et al. Cardiovascular mortality in obstructive sleep apnoea treated with continuous positive airway pressure or oral appliance: an observational study. Respirology 2014; 18: 1184-1190.

Ferguson KA, Cartwright R, Rogers R, et al. Oral appliances for snoring and obstructive sleep apnea: a review. Sleep 2006; 29: 244-262.

Liu Y, Lowe AA, Fleetham JA, et al. Cephalometric and physiologic predictors of the efficacy of an adjustable oral appliance for treating obstructive sleep apnea. Am J Orthod Dentofacial Orthop 2001; 120: 639-647.

Tsuiki S, Lowe AA, Almeida FR, et al. Effects of mandibular advancement on airway curvature and obstructive sleep apnoea severity. Eur Respir J 2004; 23: 263-268.

$\mathrm{Ng}$ AT, Qian J, Cistulli PA. Oropharyngeal collapse predicts treatment response with oral appliance therapy in obstructive sleep apnea. Sleep 2006; 29: 666-671.

$\mathrm{Ng}$ AT, Darendeliler MA, Petocz P, et al. Cephalometry and prediction of oral appliance treatment outcome. Sleep Breath 2012; 16: 47-58.

Marklund M, Stenlund H, Franklin KA. Mandibular advancement devices in 630 men and women with obstructive sleep apnea and snoring: tolerability and predictors of treatment success. Chest 2004; 125: 1270-1278.

Deane SA, Cistulli PA, Ng AT, et al. Comparison of mandibular advancement splint and tongue stabilizing device in obstructive sleep apnea: a randomized controlled trial. Sleep 2009; 32: 648-653.

9 Cartwright RD, Samelson CF. The effects of a nonsurgical treatment for obstructive sleep apnea. The tongue-retaining device. JAMA 1982; 248: 705-709.

Cartwright RD. Predicting response to the tongue retaining device for sleep apnea syndrome. Arch Otolaryngol 1985; 111: 385-388.

Cartwright R, Stefoski D, Caldarelli D, et al. Toward a treatment logic for sleep apnea: the place of the tongue retaining device. Behav Res Ther 1988; 26: 121-126.

Cartwright R. Return of the TRD. J Clin Sleep Med 2009; 5: 439-440.

Lazard DS, Blumen M, Lévy P, et al. The tongue-retaining device: efficacy and side effects in obstructive sleep apnea syndrome. J Clin Sleep Med 2009; 5: 431-438.

Douglass CW, Shih A, Ostry L. Will there be a need for complete dentures in the United States in 2020? J Prosthet Dent 2002; 87: 5-8. 
Tsuda H, Almeida FR, Walton JN, et al. Questionnaire-based study on sleep-disordered breathing among edentulous subjects in a university oral health center. Int J Prosthodont 2010; 23: 503-506.

Bucca C, Carossa S, Pivetti S, et al. Edentulism and worsening of obstructive sleep apnoea. Lancet 1999; 353: 121-122.

Bordier P, Maurice-Tison S, Ramana NK. Overdrive ventricular pacing in pacemaker recipients with permanent atrial fibrillation and sleep apnea. J Clin Sleep Med 2012; 8: 257-264.

Shalaby A, Atwood CW, Selzer F, et al. Cardiac resynchronization therapy and obstructive sleep-related breathing disorder in patients with congestive heart failure. Pacing Clin Electrophysiol 2011; 34: 593-603.

Shalaby A, Atwood CW, Hansen C, et al. Analysis of interaction of acute atrial overdrive pacing with sleep-related breathing disorder. Am J Cardiol 2007; 99: 573-578.

Simantirakis EN, Schiza SE, Chrysostomakis SI, et al. Atrial overdrive pacing for the obstructive sleep apnea-hypopnea syndrome. N Engl J Med 2005; 353: 2568-2577.

Yiu KH, Lee KL, Lau CP, et al. Alleviation of pulmonary hypertension by cardiac resynchronization therapy is associated with improvement in central sleep apnea. Pacing Clin Electrophysiol 2008; 31: 1522-1527.

Sharafkhaneh A, Sharafkhaneh H, Bredikus A, et al. Effect of atrial overdrive pacing on obstructive sleep apnea in patients with systolic heart failure. Sleep Med 2007; 8: 31-36.

Krahn D, Yee R, Erickson MK, et al. Physiologic pacing in patients with obstructive sleep apnea: a prospective, randomized crossover trial. J Am Coll Cardiol 2006; 47: 379-383.

Pépin JL, Defaye P, Garrigue S, et al. Overdrive atrial pacing does not improve obstructive sleep apnoea syndrome. Eur Respir J 2005; 25: 343-347.

Lüthje L, Renner B, Kessels R, et al. Cardiac resynchronization therapy and atrial overdrive pacing for the treatment of central sleep apnoea. Eur J Heart Fail 2009; 11: 273-280.

Busetto L, Angrisani L, Basso N, et al. Safety and efficacy of laparoscopic adjustable gastric banding in the elderly. Obesity 2008; 16: 334-338.

Thereaux J, Poitou C, Barsamian C, et al. Midterm outcomes of gastric bypass for elderly (aged $\geqslant 60 \mathrm{yr}$ ) patients: a comparative study. Surg Obes Relat Dis 2015; 11: 836-841.

Vanommeslaeghe H, Deylgat B, Van Cauwenberge S, et al. Laparoscopic Roux-en-Y gastric bypass in the elderly: feasibility, short-term safety, and impact on comorbidity and weight in 250 cases. Surg Endosc 2015; 29: 910-915.

Daley WR, Kaczmarek RG. The epidemiology of cardiac pacemakers in the older US population. J Am Geriatr Soc 1998; 46: 1016-1019.

Garrigue S, Pépin JL, Defaye $\mathrm{P}$, et al. High prevalence of sleep apnea syndrome in patients with long-term pacing: the European Multicenter Polysomnographic Study. Circulation 2007; 115: 1703-1709. 2014; 370: 139-149.

Zuberi NA, Rekab K, Nguyen HV. Sleep apnea avoidance pillow effects on obstructive sleep apnea syndrome and snoring. Sleep Breath 2004; 8: 201-207.

Javaheri S. Acetazolamide improves central sleep apnea in heart failure: a double-blind, prospective study. Am J Respir Crit Care Med 2006; 173: 234-237.

Zilberman M, Silverberg DS, Bits I, et al. Improvement of anemia with erythropoietin and intravenous iron reduces sleep-related breathing disorders and improves daytime sleepiness in anemic patients with congestive heart failure. Am Heart J 2007; 154: 870-876.

Moraes W, Poyares D, Sukys-Claudino L, et al. Donepezil improves obstructive sleep apnea in alzheimer disease: a double-blind, placebo-controlled study. Chest 2008; 133: 677-683.

Gooneratne NS, Gehrman P, Gurubhagavatula I, et al. Effectiveness of ramelteon for insomnia symptoms in older adults with obstructive sleep apnea: a randomized placebo-controlled pilot study. J Clin Sleep Med 2010; 6: 572-580.

Brunner H. Success and failure of mirtazapine as alternative treatment in elderly stroke patients with sleep apnea-a preliminary open trial. Sleep Breath 2008; 12: 281-285.

Cicolin A, Mangiardi L, Mutani
Mayo Clin Proc 2006; 81: 53-55.

Sun H, Palcza J, Rosenberg R, et al. Effects of suvorexant, an orexin receptor antagonist, on breathing during sleep in patients with chronic obstructive pulmonary disease. Respir Med 2015; 109: 416-426.

Frohnhofen H, Roffe C. Successful treatment of Charles Bonnet syndrome with nocturnal oxygen supplementation. J Am Geriatr Soc 2010; 58: 2241-2242.

Frohnhofen H, Heuer HC, Kanzia A, et al. Influence of type of treatment for sleep apnea on activities of daily living in a sample of elderly patients with severe sleep apnea. J Physiol Pharmacol 2009; 60: Suppl. 5: 51-55.

Oksenberg A, Gadoth N. Are we missing a simple treatment
of the supine sleep position. J Sleep Res 2014; 23: 204-210.

Oksenberg A, Silverberg DS. The effect of body posture on sleep-related breathing disorders: facts and therapeutic implications. Sleep Med Rev 1998; 2: 139-162.

Bliwise DL, Benkert RE, Ingham RH. Factors associated with nightly variability in sleep disordered breathing in the elderly. Chest 1991; 100: 973-977.

Epstein LJ, Kristo D, Strollo PJ Jr, et al. Clinical guideline for the evaluation, management and long-term care of obstructive sleep apnea in adults. J Clin Sleep Med 2009; 5: 263-276.

MJL, van Maanen JP, Dun L, et al. The undervalued potential of positional therapy in position-dependent snoring and obstructive sleep apnea - a review of the literature. Sleep Breath 2013; 17: 39-49. Schramm PJ, Thomas RJ. Assessment of therapeutic options for mild obstructive sleep apnea using cardiopulmonary coupling measures. J Clin Sleep Med 2012; 8: 315-320.

Maurer JT, Stuck BA, Hein G, et al. Treatment of obstructive sleep apnea with a new vest preventing the supine position. Dtsch Med Wochenschr 2003; 128: 71-75.

Eijsvogel MM, Ubbink R, Dekker J, et al. Sleep position trainer versus tennis ball technique in positional obstructive sleep apnea syndrome. J Clin Sleep Med 2015; 11: 139-147.

de Vries GE, Hoekema A, Doff MHJ, et al. Usage of positional therapy in adults with obstructive sleep apnea. J Clin Sleep Med 2015; 11: 131-137. 
Aurora RN, Chowdhuri S, Ramar K, et al. The treatment of central sleep apnea syndromes in adults: practice parameters with an evidence-based literature review and meta-analyses. Sleep 2012; 35: 17-40.

Morgenthaler TI, Kapen S, Lee-Chiong T, et al. Practice parameters for the medical therapy of obstructive sleep apnea. Sleep 2006; 29: 1031-1035.

Mason M, Welsh EJ, Smith I. Drug therapy for obstructive sleep apnoea in adults. Cochrane Database Syst Rev 2013; 5: CD003002.

Castillo JL, Menendez P, Segovia L, et al. Effectiveness of mirtazapine in the treatment of sleep apnea/hypopnea syndrome (SAHS). Sleep Med 2004; 5: 507-508.

Westwood AJ, Vendrame M, Montouris G, et al. Pearls \& oysters: treatment of central sleep apnea with topiramate. Neurology 2012; 78: 97-99.

Dekok HJM. Case report: the medical treatment of obstructive sleep apnoea syndrome (OSAS) with Selenium. Med Hypotheses 2005; 65: 817-818.

Kohen I, Sarcevic A. Central sleep apnea in a geriatric patient treated with aripiprazole. Am J Ther 2009; 16: 197-198.

Zimmerman ME, Aloia MS. Sleep-disordered breathing and cognition in older adults. Curr Neurol Neurosci Rep 2012; 12: 537-546.

Verstraeten E. Neurocognitive effects of obstructive sleep apnea syndrome. Curr Neurol Neurosci Rep 2007; 7: $161-166$.

Sforza E, Roche F. Sleep apnea syndrome and cognition. Front Neurol 2012; 3: 87.

Morrell MJ, Twigg G. Neural consequences of sleep disordered breathing: the role of intermittent hypoxia. Adv Exp Med Biol 2006; 588: 75-88.

Jackson ML, Howard ME, Barnes M. Cognition and daytime functioning in sleep-related breathing disorders. Prog Brain Res 2011; 190: 53-68.

Yaffe K, Laffan AM, Harrison SL, et al. Sleep-disordered breathing, hypoxia, and risk of mild cognitive impairment and dementia in older women. JAMA 2011; 306: 613-619. daily living in elderly patients. J Physiol Pharmacol 2007; 58 Suppl 5: 185-191.

Toschi-Dias E, Trombetta IC, Dias da Silva VJ, et al. Time delay of baroreflex control and oscillatory pattern of sympathetic activity in patients with metabolic syndrome and obstructive sleep apnea. Am J Physiol Heart Circ Physiol 2013; 304: 1038-1044.

Mehta V, Vasu TS, Phillips B, et al. Obstructive sleep apnea and oxygen therapy: a systematic review of the literature and meta-analysis. J Clin Sleep Med 2013; 9: 271-279.

Gottlieb DJ, Punjabi NM, Mehra R, et al. CPAP versus oxygen in obstructive sleep apnea. N Engl J Med 2014; 370: 2276-2285.

Bardwell WA, Ancoli-Israel S, Berry CC, et al. Neuropsychological effects of one-week continuous positive airway pressure treatment in patients with obstructive sleep apnea: a placebo-controlled study. Psychosom Med 2001; 63: 579-584.

Pokorski M, Jernajczyk U. Nocturnal oxygen enrichment in sleep apnoea. J Int Med Res 2000; 28: 1-8.

Phillips BA, Schmitt FA, Berry DT, et al. Treatment of obstructive sleep apnea. A preliminary report comparing nasal CPAP to nasal oxygen in patients with mild OSA. Chest 1990; 98: 325-330.

Landsberg R, Friedman M, Ascher-Landsberg J. Treatment of hypoxemia in obstructive sleep apnea. Am J Rhinol 2001; 15: 311-313.

Dempsey JA, Veasey SC, Morgan BJ, et al. Pathophysiology of sleep apnea. Physiol Rev 2010; 90: 47-112.

Frohnhofen H, Hoeltmann B, Orth G. Acceptance of NCPAP in a sample of patients admitted for geriatric rehabilitation. Eur J Med Res 2009; 14 Suppl 4: 82-85.

Aoki K, Matsuo M, Takahashi M, et al. Association of sleep disordered breathing with decreased cognitive function among patients with dementia. J Sleep Res 2014; 23: 517-523.

Martin MS, Sforza E, Roche F, et al. Sleep breathing disorders and cognitive function in the elderly: An 8 year follow up study. The PROOF synapse cohort. Sleep 2015; 38: 179-187.

Blackwell T, Yaffe K, Laffan A, et al. Osteopporotic fractures in men study group. J Am Geriatr Soc 2015; 63: 453-461.

Jennum P, Tønnesen P, Ibsen R, et al. All cause mortality from obstructive sleep apnea in male and female patients with and without continuous positive airway pressure treatment: a registry study with 10 years of follow up. Nat Sci Sleep 2015; 7: 43-50.

8 Veasey SC, Guilleminault C, Strohl KP, et al. Medical therapy for obstructive sleep apnea: a review by the Medical Therapy for Obstructive Sleep Apnea Task Force of the Standards of Practice Committee of the American Academy of Sleep Medicine. Sleep 2006; 29: 1036-1044.

Zulman DM, Sussman JB, Chen X, et al. Examining the evidence: a systematic review of the inclusion and analysis of older adults in randomized controlled trials. J Gen Intern Med 2011; 26: 783-790. 